DEPARTMENT OF THE INTERIOR UNITED STATES GEOLOGICAL SURVEY GEORGE OTIS SMITH, DIRECTOR

\title{
BULLETIN 479
}

\section{THE}

\section{GEOCHEMICAL INTERPRETATION OF WATER ANALYSES}

BY

CHASE PALMER

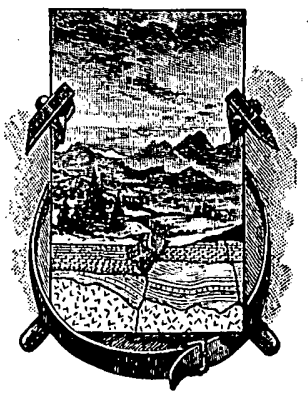

W A SHIN GT ON

GOVERNMENT PRINTING OFFICE 



\section{CONTENTS.}

Expression of

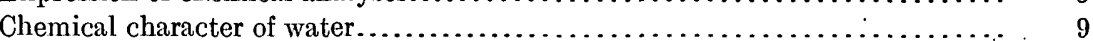

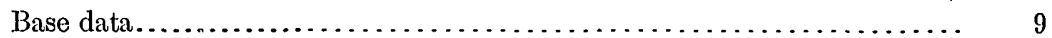

Water of Lake Champlain..$\ldots \ldots \ldots \ldots \ldots \ldots \ldots \ldots \ldots \ldots \ldots \ldots \ldots \ldots$

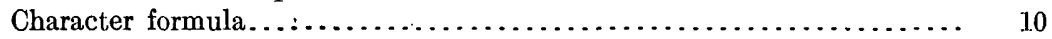

Properties of natural waters......................... 11

Classification of waters. . . . . . . . . . . . . . . . . . . . . . . . .

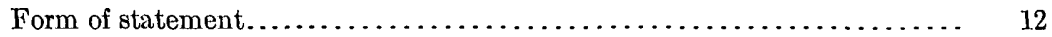

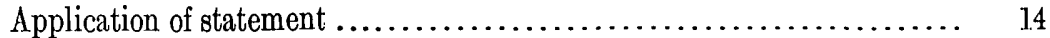

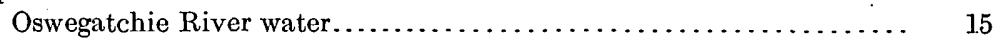

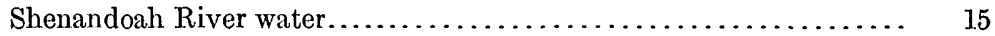

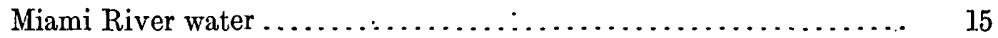

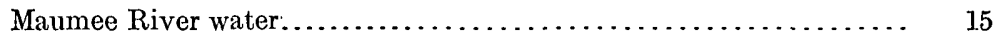

Brine from Highland, Ill . . . . . . . . . . . . . . . . . . . 15

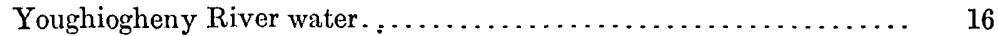

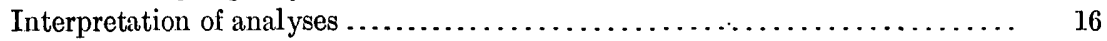

River waters in the Southern States. .................... 16

Relation of water properties to geologic formations. . . . . . . . . . 18

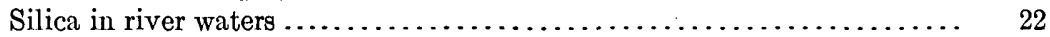

Relation of silica to primary alkalinity . . . . . . . . . . . . . . . 22

Silica in waters of the Piedmont Plateau and Coastal Plain of the Gulf

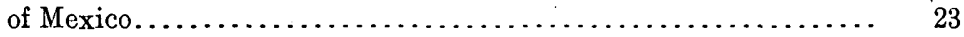

Other rivers draining areas of crystalline rocks .............. 24

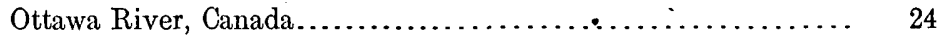

Mahanuddy River, India, and Uruguay River, Brazil........ 26

Persistence of silica in river waters. . . . . . . . . . . . . . . . 27

The water of Mississippi River. ....................... 28

The water of the Great Lakes and St. Lawrence River. . . . . . . . . . 29

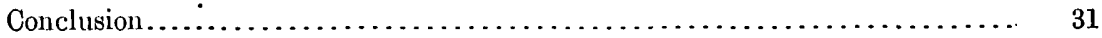

\section{ILLUSTRATION.}

Figure 1. Map showing geologic character of the drainage basins of Shenandoah; James, Roanoke, and Dan rivers. 



\title{
THE GEOCHEMICAL INTERPRETATION OF WATER ANALYSES.
}

\author{
By Chase Palmer.
}

\section{EXPRESSION OF CHEMICAL ANALYSES.}

Terrestrial waters are essentially solutions of a few salts, and their chemical character, like that of solutions in general, depends on the nature and proportion of the substances they contain. The interpretation of the chemical character of a water from the results of analysis is necessarily uncertain and unsatisfactory if it is based merely on the amounts of the radicles determined. In analytical chemistry, as in other branches of the science, the chemist considers the inherent properties of the radicles of substances, and hence his statement of the results of a water analysis should be framed in accordance with the chemical nature and the proportional amounts of the radicles determined in a solution of mixed salts. There is no lack of information concerning the amounts of the various materials dissolved in natural waters and the mutual relations of their parts. What the chemist especially needs is a form of statement that will adequately express these relations and disclose the true proportions of the radicles.

The engineer has always recognized the importance of determining the properties of water without recourse to complete chemical analysis, and his attention is naturally directed to those properties which are objectionable. In 1841 Thomas Clark patented in England a process for removing the objectionable constituents of hard waters. The softening agent used by Clark was lime water, the action of which depends on a very simple principle. In contact with lime water the soluble calcium bicarbonate in hard water is changed to insoluble calcium carbonate and precipitated, the hardening constituent, calcium, being removed simultaneously from the hard water and from the softening agent.

The reaction may be expressed by the equation-

$$
\mathrm{CaH}_{2}\left(\mathrm{CO}_{3}\right)_{2}+\mathrm{Ca}(\mathrm{OH})_{2}=2 \mathrm{CaCO}_{3}+2 \mathrm{H}_{2} \mathrm{O}
$$

This process of improving the quality of water at once acquired wide popularity. In response to many requests for information respecting his methods of examining waterg, in 1847 Clark $^{1}$ addressed

\footnotetext{
1 Clark, Thomas, On the examination of water for towns, for jts hardness, and for the incrustation it
} deposits on boiling: Chemical Gazette, vol. 5, 1847, p. 100. 
to friends a circular letter in which he states that his examination of .waters involves two processes-one for ascertaining the hardness of water and one for ascertaining its alkalinity. The degrees of permanent hardness, temporary hardness, permanent alkalinity, and acidity are now capable of exact measurement by methods which do not involve the determination of the constituents of water. In the section on the properties of water definite limits, deducible from the results of a complete chemical analysis, will be set to the special properties. The limits there assigned conform to the measurements of hardness and alkalinity if made according to the exact method of Hehner as described by Sutton. ${ }^{1}$. The acidity of water may be determined by direct measurement, made by neutralizing a known quantity of the acid water by a standard alkaline solution. Saltness caused by dissolved neutral salts is a general property of natural water. Since the alkalies and strong acids. contribute largely to this property, it is essential that the proportional amounts of the alkalies and strong acids be separately determined. From the data thus obtained, the full value of the salinity - the saltness - of water may be determined.

It is to be observed that Clark fully recognized the propriety of looking to some of the properties of water for information concerning its fitness for domestic and industrial uses, and the benefit of his invention to modern civilization is beyond estimate. In problems involving the chemical action of water it is important to-day that the student consider all the properties conferred on water by all the substances dissolved in it, for in the totality of its properties lies the full power of water as a chemically active agent.

Two forms of stating the amounts of mineral materials dissolved in water have been widely used. These forms are typified by the following analysis of sea water: ${ }^{2}$

Composition of ocean water.

\begin{tabular}{|c|c|c|c|}
\hline \multicolumn{2}{|c|}{ Amounts assigned to hypothetical combinations. } & \multicolumn{2}{|c|}{ Amounts assigned to radicles. } \\
\hline Combinations. & $\begin{array}{l}\text { Milligrams } \\
\text { per liter. }\end{array}$ & Radicles. & $\begin{array}{l}\text { Milligrams } \\
\text { per liter. }\end{array}$ \\
\hline 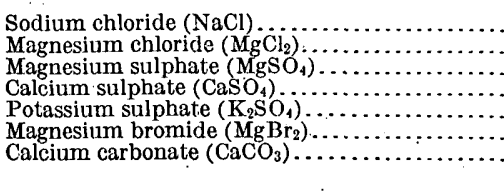 & $\begin{array}{r}27,215 \\
3,807 \\
1,658 \\
1,260 \\
863 \\
76 \\
121\end{array}$ & 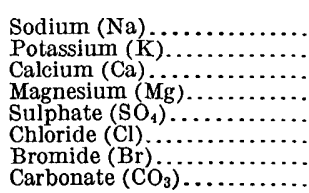 & $\begin{array}{r}10,710 \\
390 \\
420 \\
1,300 \\
2,700 \\
19,350 \\
60 \\
70\end{array}$ \\
\hline & 35,000 & 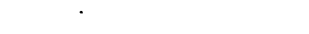 & 35,000 \\
\hline
\end{tabular}

1 Volumetric analysis, 9th ed., p. 70.

2 Mean of 77 analyses, by W. Dittmar,-of sea water collected by the Challenger expedition: Challenger Report, Physics and chemistry, vol. 1, 1884, p. 203. 
The older form, which represents the radicles as grouped together in arbitrary combinations, has by no means lost all adherents. It seems to be held in especial favor by the engineer because it gives the amount of dissolved material in terms which enable him to determine the corresponding amounts of substances necessary to fit a water for special industrial uses. The geologist, however, long ago realized that this form of expressing the chemical character of a water is inadequate to the exacting demands of research and has resorted to the form of statement in which the amounts of the radicles determined are given as independent units. In other words, he has practically abandoned a form of chemical expression and has adopted instead a statement of physical results. Chemical literature furnishes abundant evidence that the statement of water analyses in a form which does not recognize the proportional reaction capacity of the radicles fails to show the chemical character of the waters. Waters differing widely in character may be grouped together as similar if the classification is based on the preponderance of any radicle that may be considered as dominant in a solution of salts or on the apparent predominance of two or more radicles selected merely because they contribute largely to the weight of the mixture. Such classifications may be interesting, from several points of view; but they are unreliable guides to the solution of geologic problems involving chemical processes. Furthermore, chemists, whose attention is fixed on the physical weights of the radicles, which are assumed to be free and independent, may easily fail to observe important facts concerning the chemical character of waters, especially facts relating to geology.

One advantage of the ionic form of stating water analyses is that it assigns weights directly to the chemically active parts of the dissolved substances instead of using those parts to build imaginary. structures. The statement of the amounts of the radicles, however, indicates only the chemical composition of a water, not its character, for the physical weight of a radicle is no criterion of its chemical value in a system of dissolved salts such as exists in water. On the other hand, if the radicles are considered not as matter subject. only to the law of gravitation, but rather as individuals acting together under the law of equivalent combining weights, contributing their proportional shares to the final balance of the system, the meaning of the results of a mineral analysis of water can be expressed clearly and precisely.

The reaction capacities of the radicles of the salts dissolved in water are the quotients obtained by dividing the weight of each radicle by its corresponding equivalent combining weight. The reaction capacity may be more logically determined by using for factors the reciprocals of the equivalent combining weights of the 
radicles, according to the practice of Herman Stabler, in interpreting the results of water analyses for industrial purposes. ${ }^{1}$ Stabler defines "reaction coefficient" as the chemical reacting power of a unit weight of a radicle. The reaction coefficient of a radicle is the ratio of the reaction capacity of 1 part of that radicle to the reaction capacity of 8 parts of oxygen and is computed as follows:

\begin{tabular}{|c|c|c|c|}
\hline . & $\begin{array}{c}\text { Atoinic } \\
\text { weights. }\end{array}$ & $\begin{array}{c}\text { Equivalent } \\
\text { weights. }\end{array}$ & $\begin{array}{l}\text { Reaction } \\
\text { coefficient. }\end{array}$ \\
\hline Oxygen.. & 16 & 16 & . \\
\hline Hydrogen.... & 1.008 & $1.008=1.008$ & $=0.992$ \\
\hline Calcium.. & 40.09 & $\underline{40.09}=20$ & $\begin{array}{l}1.008 \\
1 \\
\end{array}$ \\
\hline Magnesium. . & 24.32 & $\frac{24.32}{2}=12.16$ & $\frac{1}{12.16}=.0822$ \\
\hline
\end{tabular}

The other reaction coefficients are similarly obtained.

The product of the "reaction coefficient" by the amount of a radicle Stabler calls the "reacting value" of that amount of the radicle. These terms are peculiarly adapted to the chemical valuation of radicles determined in mixtures, and they will be adopted here in the chemical classification of waters. The following table shows the positive and negative radicles usually found in surface waters and their reaction coefficients:

Positive and negative radicles, with reaction coefficients.

\begin{tabular}{|c|c|c|c|}
\hline Positive radicles: & $\begin{array}{l}\text { Reaction } \\
\text { coefficients. }\end{array}$ & Negative radicles. & $\begin{array}{c}\text { Reaction } \\
\text { coefficients. }\end{array}$ \\
\hline 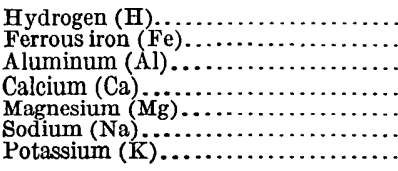 & $\begin{array}{l}0.992 \\
.0358 \\
.1107 \\
.0499 \\
.0822 \\
.0435 \\
.0256\end{array}$ & 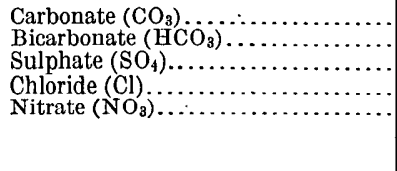 & $\begin{array}{r}0.0333 \\
.0164 \\
.0208 \\
.0282 \\
.0161\end{array}$ \\
\hline
\end{tabular}

Stabler prefixes the letter $r$ to the symbol of a radicle to designate the reacting value of the radicle, and the same symbolization will be used in this report.

Under the name "milligram equivalents" (that is, equivalents of milligrams of hydrogen) chemists have long used the reacting values of the radicles for two purposes-namely, to determine the accuracy of the analysis of a water and to obtain reliable factors to be used in the construction of hypothetical combinations. Stabler has shown that the reacting values may be put to a better use, for he has demonstrated mathematically that the analytical results can be

1 Stabler, Herman, The mineral analysis of water for industrial purposes and its interpretation by the engineer: Eng. News, vol. 60,1908, p. 356. Also, chapter on the industrial application of water analyses in Water-Supply Paper U. S. Geol. Survey No. 274, 1911, pp. 165-181. 
- Interpreted far more satisfactorily directly from the reacting values than from their hypothetical combinations, and he has shown that the labor of calculating the amounts of remedial agents required to produce desired changes in the character of a water is thereby reduced: to a minimum.

\section{CHEMICAL CHARACTER OF WATER.}

\section{BASE DATA.}

The investigation of the surface waters of the United States, concluded in 1908 by the water resources branch of the United States Geological Survey, has accumulated a store of information concerning the amounts of inorganic material contained in the river waters of the country. During the progress of the investigation the writer studied the composition of the water of many rivers, and though he observed great diversity in the composition of the waters, he was convinced that the waters in one locality could not be differentiated in chemical character from the waters in other localities if the analytical results were stated in amounts of the radicles determined. $\mathrm{He}$ is satisfied, however, that the statement of the radicles can be used satisfactorily for interpreting the character of water solutions if the chemical values involved are made the basis of interpretation, and he therefore presents for consideration the chemical classification of waters here described. To illustrate the principle on which the new classification is based the results of analyses of the water of Lake Champlain will be used, and one of the properties of the water will be deduced by direct resort to the chemical values of the radicles contained in it.

\section{WATER OF LAKE CHAMPLAIN.}

The average results of analyses ${ }^{1}$ of four separate samples collected at four different points on Lake Champlain are shown below.

Results of four analyses of water of Lake Champlain.

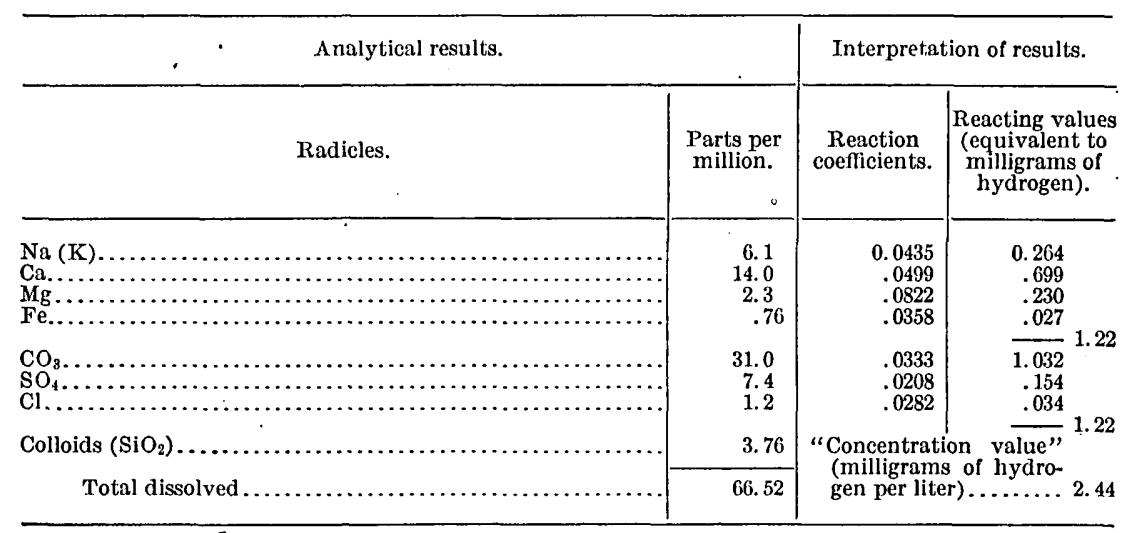

1 Leighton, M. O., Preliminary report on the pollution of Lake Champlain: Water-Supply Paper U..S. Geol. Survey No. 121, 1905, p. 20. 
The weights of the radicles have thus been resolved to values which are chemically measurable by a common standard. The unit of measurement is the milligram of hydrogen, in conformity with the international acceptance of hydrogen as the standard of reaction capacity. At first sight the reacting values may seem insignificant, but they disclose an important quality of the water of Lake Champlain. The reacting value of the alkalies (0.264) exceeds the sum of the reacting values of the sulphates and chlorides (0.188) by 0.076 . This excess of alkalinity may be expressed in terms of sodium carbonate by multiplying 0.076 , its reacting value, by 53 , the combining weight of sodium carbonate. The product, 4.02 , represents the parts of sodium carbonate per million parts of water. Surface waters distinguished by alkalinity due directly to the alkalies are not usually found in drainage basins whose rocks consist entirely of calcareous formations. The excessive alkalinity suggests that the lake receives water that has come from the massive rocks of the mountains, and that these waters contain carbonates of the alkalies in quantity sufficient to overcome all the permanent hardness of the waters derived from more recent formations and to render the lake permanently alkaline.

\section{CHARACTER FORMULA.}

Different waters are solutions having different degrees of concentration, and the degree of concentration of the water from a given source is subject to continual change. The application of the reacting values of the radicles to the character of water is therefore restricted to the particular water and to that water at the time it was sampled for analysis.

If, however, the reacting values are expressed in terms from which the concentration factor is omitted they become capable of wide application. Such an expression may be considered the character formula for the mixture of salts dissolved in a water. For convenience 100 has been selected as the formula weight, and the reacting value of each radicle in the formula is therefore expressed as a per cent of the concentration value. This formula weight has been found to be applicable to the many waters that have come under the writer's observation. Thus the character formula not only shows at a glance the chemical proportions of the radicles found in a water, but also clearly discloses even slight differences in the proportions of the radicles in waters under comparison, as may be seen by comparing, for example, the character formulas of the waters cited in Table 1, opposite page 14. The changes, moreover, in the chemical proportions of the radicles present in a river water at different stations along its course are brought out in strong relief by the use and application of this formula. These changes are shown in 
the tabulated character formulas of the Mississippi River water at the several stations from Minneapolis to New Orleans. The character formula adopted for the comparative study of water is strictly a chemical formula. It invokes the support of no hypothesis, but rests solely on the fundamental law of equivalent combining weights.

In order to show the chemical character of mineral waters with especial reference to their therapeutic action, Carl von Than ${ }^{1}$ many years ago devised a form of expression that was also based on the law of equivalents. Von Than's expression involved two separate ratings, one for the reacting values of all the positive radicles and one for the reacting values of all the negative radicles, the basis of each rating being 100 . This double rating makes the resulting expression too cumbrous for ready interpretation. The character formula here proposed refers the reacting values of all the radicles in the system of dissolved salts to one aggregate, so that the characterization of the water solution is greatly simplified.

PROPERTIES OF NATURAL WATERS.

Nearly all terrestrial waters have two general properties, salinity. and alkalinity, on whose relative proportions their fundamental characters depend. Salinity is caused by salts that are not hydrolyzed; alkalinity is attributed to free alkaline bases produced by the hydrolytic action of water on solutions of bicarbonates and on solutions of salts of other weak acids.

All the positive radicles, including hydrogen, may participate in producing salinity; but of the negative radicles only those of the actively strong acids can perform a similar function. The principal strong acids in natural waters are represented by the sulphates, chlorides, and nitrates. Since salinity depends on the combined activity of equal values of both positive and negative radicles, and since its degree is limited only by the reacting values of the strong acids, the full value of salinity is obtained by multiplying the total value of the strong acid radicles by 2 .

The full value of alkalinity and at the same time due recognition of the parent substances which are the source of alkalinity can be obtained by doubling the values of the bases in excess of the values of the strong acids.

The positive radicles determined in a water analysis, in accordance with their properties, fall naturally into three groups, as follows:

Group $a$. Alkalies (sodium, potassium, lithium). Their salts are readily soluble in water. They do not cause hardness.

Group $b$. Earths or alkaline earths. Calcium and magnesium are the chief representatives of this group. Many of their saltsare

1 Sitzungsberichte der Kaiserl. Akad. der Wissenschaften [Vienna], Band 51, 2te Abthellung (1865), p. 347 . 
sparingly soluble in water. They cause the property commonly known as hardness.

Group c. Hydrogen. Salts of hydrogen are acids and cause acidity in waters.

The groups of positive radicles are measured by the sum of the reacting values of their members, and in accordance with the prevalence of the reacting values of the groups of positive radicles in the system, five special properties are possible, namely:

1. Primary salinity (alkali salinity); that is, salinity not to exceed twice the sum of the reacting values of the radicles of the alkalies.

2. Secondary salinity (permanent hardness); that is, the excess (if any) of salinity over primary salinity, not to exceed twice the sum of the reacting values of the radicles of the alkaline earths group.

3. Tertiary salinity (acidity); that is, the excess (if any) of salinity over primary and secondary salinity.

4. Primary alkalinity (permanent alkalinity); that is, . the excess (if any) of twice the sum of the reacting values of the alkalies over salinity.

5. Secondary alkalinity (temporary alkalinity); that is, the excess (if any) of twice the sum of the reacting values of the radicles of the alkaline earths group over secondary salinity.

In distinguishing the special properties, the values of radicles of the same sign are doubled. By this procedure the positive and negative radicles, which together induce the special properties, receive their full value. The use of the adjectives "primary" and "secondary" to qualify the general properties of the water solution associates naturally the alkalies with the oldest rock formations, of which the alkalies are the principal soluble decomposition products, and refers the alkaline earths to the more recent formations as their principal sources.

The character of natural waters with reference to the lithology of the region from which they are derived, to their solvent action on minerals with which they may come in contact, to sedimentary deposits that they are likely to form, to their effect on industrial processes, and to their chemical action in general can best be portrayed by a statement of as many of the five special properties above mentioned as may be found, expressed in percentages of their totality.

\section{CLASSIFICATION OF WATERS.}

\section{FORM OF STATEMENT.}

The reaction properties of the water solution are fixed by the relative values of three of the five groups of radicles producing the five special properties of natural waters. The numerical relations of the value of the group of strong acids to the values of groups of positive radicles have been made the basis of the following clsssification. 
Let $a, b, d$ represent, respectively, the percentage values of the alkalies, earths, and strong acids. Any one of five conditions may exist: $d$ may be less than $a$; equal to $a$; greater than $a$ and less than $a+b$; equal to $a+b$; or greater than $a+b$. The five classes of waters resulting from these conditions are given below, with their attendant properties of reaction.

Cliass 1.

( $d$ less than $a$.)

$2 d . . . . . . .$. Primary salinity.

$2(a-d) \ldots .$. . Primary alkalinity.

$2 b \ldots . . . .$. Secondary alkalinity.

Class 2.

( $d$ equal to $a$.

$2 a$ or $2 d \ldots . .$. Primary salinity.

$2 b \ldots \ldots . .$. Secondary alkalinity.

Class 3.

(d greater than $a ; d$ less than $a+b$.

$2 a . . . . . .$. Primary salinity.

$2(d-a) \ldots . .$. Secondary salinity.

$2(a+b-d)$... Secondary alkalinity.
ClaAsS 4.

( $d$ equal to $a+b$.

$2 a \ldots . . . .$. Primary salinity.

$2 b \ldots \ldots$. Secondary salinity.

ClaAsS 5.

( $d$ greater than $a+b$.)

$2 a \ldots . . . .$. . Primary salinity.

$2 b \ldots \ldots . . .$. Secondary salinity.

$2(d-a-b) \ldots$ Tertiary salinity (acidity).

To dispel any perplexity that may possibly exist in the minds of those unfamiliar with the mode here used of expressing chemical values that are numerically coordinate, the relations of the properties of water to the reacting values of the radicles are stated again in a slightly modified form.

Class 1.-Strong acids less than alkalies.

\begin{tabular}{|c|c|c|c|c|}
\hline & & ( $d$ less than $a)$. & & \\
\hline Property values. & & Reacting values. & & \\
\hline Primary salinity & $=$ & Strong acids & $=$ & $d$ \\
\hline Primary alkalinity & $=$ & Alkalies-strong acids & $=$ & $a-d$ \\
\hline $\begin{array}{l}\text { Secondary alkalinity } \\
\text { Gence: }\end{array}$ & $=$ & Earths & $=$ & $b$ \\
\hline Total salinity & $=$ & Strong acids $\times 2$ & $=$ & $2 d$ \\
\hline Total alkalinity & $=$ & (Bases - strong acids) $\times 2$ & $=$. & $2(a+b-d)$ \\
\hline
\end{tabular}

Cuass 2.-Sirong acid́s equal to alkalies.

$$
\text { ( } d \text { equal to } a . \text { ) }
$$

Property values. Reacting values.

$\frac{1}{2}$ Primary salinity $=$ Alkalies $\frac{1}{2}$ Secondary alkalinity $=$ Earths $=a$ or $d$ Hence:

Total salinity $\quad=$ Alkalies $\times 2$

Total alkalinity $=$ Earths $\times 2$

$$
={ }^{\cdot} b
$$

$=2 a$ or $2 d$

$=2 b$ 
CLAss 3.-Strong acids greater than alkalies, and less than bases

( $d$ greater than $a ; d$ less than $a+b$.

Property values.

$\frac{1}{2}$ Primary salinity

$\frac{1}{2}$ Secondary salinity

Reacting values.

$\frac{1}{2}$ Secondary alkalinity

Hence:

Total salinity

Total alkalinity.

$$
\begin{aligned}
& =\text { Alkalies } \quad \doteq a \\
& =\text { Strong acids-alkalies }=d-a \\
& =\text { Bases - strong acids } \quad=a+b-d \\
& =\text { Strong acids } \times 2 \quad=2 d \\
& =(\text { Bases }- \text { strong acids }) \times 2=2(a+b-d)
\end{aligned}
$$

Class 4.-Strong acids equal to bases.

( $d$ equal to $a+b$ )

Property values.

$\frac{1}{2}$ Primary salinity

$\frac{1}{2}$ Secondary salinity

Hence:

Total salinity

Reacting values.

$$
\begin{array}{ll}
=\text { Alkalies } & =a \\
=\text { Earths } & =b
\end{array}
$$

$$
=(\text { Alkalies }+ \text { earths }) \times 2 \quad=2(a+b) \text { or } 2 d
$$

Class 5.-Strong arids greater than bases.

(d greater than $a+b$.)

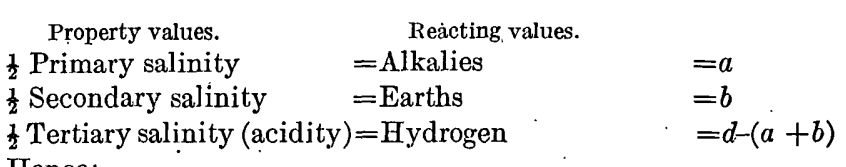

Hence:

Total salinity $\quad=$ Strong acids $\times 2=2 d$

The form in which the analytical results are stated is especially serviceable in the practical study of water as a geologic agent. The statement shows: First, the properties of the solution in percentage proportions; second, the percentage reacting values of coordinate radicles, from which the properties of reaction may be directly derived, accompanied by a statement of concentration values in milligrams per liter; third, the character formula-the percentage reacting values of the individual radicles determined-together with a statement of the concentration value; fourth, the base analyses.

The amount of any radicle may be obtained by using the following formula:

Radicle in milligrams per liter $=\frac{\text { Percentage value } \times \text { concentration value }}{100 \times \text { reaction coefficient }}$

or, the amount of any radicle may be obtained by dividing the reacting value of the radicle by its reaction coefficient.

\section{APPLICATION OF STATEMENT.}

Waters representing these five classes are found in nature. Surface waters appear to belong chiefly to the first three classes, class 4 is represented in sea water and brines and class 5 is exemplified by mine waters and by waters of volcanic origin. Examples of waters representing these five classes are given in Table 1. 
$T_{\triangle B B E}$ 1.-Classification of typical waters.

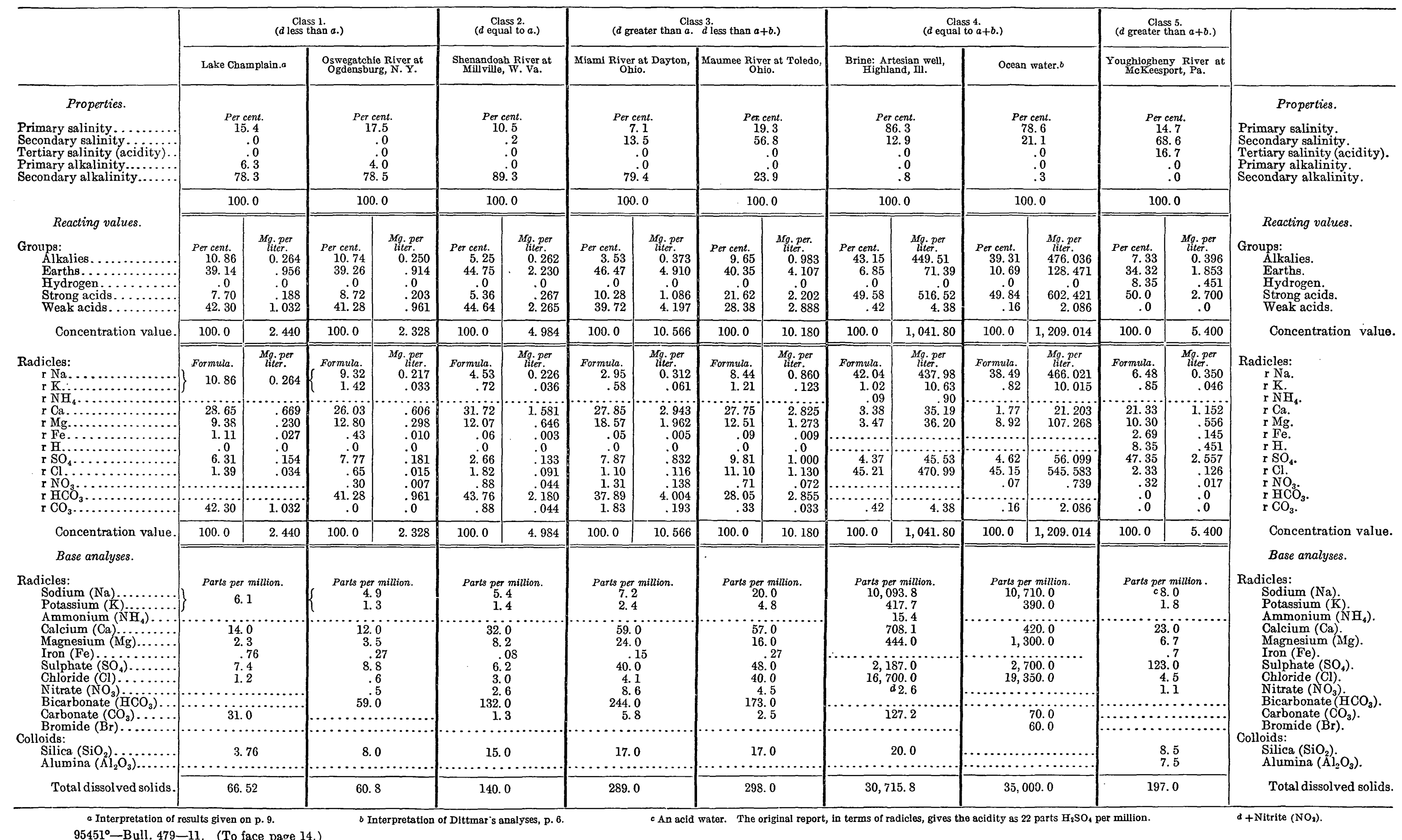


The character of the waters of Shenandoah, Miami, Maumee, and Youghiogheny rivers is interpreted directly from the results of the analyses as reported in Water-Supply Paper 236 of the United States Geological Survey.

Oswegatchie River water-Average of 15 analyses of composite samples made up of 10 samples collected on 10 consecutive days, collections taken from April 10 to September 9, 1907. Analysts, R. B. Dole, W. D. Collins, and Chase Palmer.

The properties of the Oswegatchie River water resemble closely those of the still waters of Lake Champlain, whose primary salinity is 15.4, primary alkalinity 6.3, and secondary alkalinity 78.3. Thus Lake Champlain, east of the Adirondacks, is receiving primary-alkaline waters from the mountains, and the Oswegatchie, flowing from the western slope of the mountains, is delivering primary-alkaline waters to the St. Lawrence.

Shenandoah River water.-Average of analyses of 36 composite samples. Samples collected daily from September 12, 1906, to September 9, 1907.

As the Shenandoah drains an area whose rocks comprise the older limestone formations, the peculiar character of this water is not surprising. Waters in which hardness coincides with alkalinity may be formed in other sections of the country by proper admixture of primary with secondary waters.

Miami River water.-A'verage of anayses of 34 composites. Samples collected daily from September 16, 1906, to September 17, 1907 . The properties are those normal to the water of a river traversing sedimentary rocks. The alkalies are low and, as is common in river waters in regions of Carboniferous ${ }_{a}$ rocks, their reacting values exceed the reacting value of chlorine.

Maumee River water.-Average of analyses of 36 composites. Samples collected daily from September 9, 1906, to September 7, 1907. Salinity is a very prominent property of the water. The excess of the chlorine value over the value of the alkalies, as shown in the character formula, is abnormal for rivers fed entirely by surface streams. This peculiarity of the Maumee water is discussed on page 30 .

Brine from Highland, $\Pi l l$.-This water was collected in October, 1910, from a Madison County well 1,100 feet deep. The analysis, for which the writer is indebted to Dr. Edward Bartow, director of the IIlinois State Water Survey, is an important contribution to the geology of deep-seated salt waters. ${ }^{1}$ The relative importance of the minor constituents is well shown by the new form of interpretation. In the original statement, for instance, the calcium and magnesium radicles in milligrams per liter are reported to be $\mathrm{Ca} 708.1, \mathrm{Mg}$ 444.0,

\footnotetext{
${ }^{1}$ For the chemical character of surface waters in Illinois, see W. D. Collins, The quality of the surfaoe waters of Illinois: Water-Supply Paper U. S. Geol. Survey No. 239, 1910.
} 
and in combinations the same radicles are distinguished as $\mathrm{CaSO}_{4} 2115.5, \mathrm{CaCO}_{3} 212.0, \mathrm{MgCl}_{2} 1033.0, \mathrm{MgSO}_{4}$ 875.0. Under either form of statement the calcium, by reason of its superior weight, might be considered the dominant radicle; direct comparison of the chemical values observable in the character formula of this brine shows, however, that as a factor of property magnesium exceeds calcium by a narrow margin.

Youghiogheny River water.-The high acidity of the Youghiogheny indicates that the river receives water from coal mines. The mode of expressing acidity by the new system is in perfect accord with the mode of expressing other properties. Acidity can not be adequately expressed by the so-called ionic form of statement, which is intended to show merely the composition of the water, and not its properties.

\section{INTERPRETATION OF ANALYSES.}

Some examples, offered to illustrate the application of the principles on which the rational interpretation of water analyses is based, will now be presented.

The river waters belonging to the Piedmont Plateau and Coastal Plain will be described, the relation of the properties of river waters to geologic formations will be considered, the analyses of the waters of three great rivers will be interpreted in connection with a discussion of dissolved silica in flowing waters, some of the changes in the character of the water of Mississippi River will be noted, and finally the changes in the character of the waters of the Great Lakes will receive attention.

\section{RIVER WATERS IN THE SOUTHERN STATES.}

The area drained by the rivers of the Piedmont Plateau and Coastal Plain extends from James River, in Virginia, to Pearl River, in Mississippi, and comprises about 125,000 square miles. The waters studied were taken from rivers in Virginia, North Carolina, South Carolina, Georgia, Alabama, and Mississippi. In the beginning of the investigation of these southern waters several serious obstacles were encountered, and it is, therefore, advisable to limit the consideration of the chemical character of these waters to the analyses made in the later part of the investigation, when conditions were most favorable for obtaining reliable results.

Complete analyses of river waters in Southern States appear in Tables 2 and 3, one covering the south Atlantic coast rivers from the Piedmont Plateau and the other the Coastal Plain rivers tributary to the eastern Gulf of Mexico. 
$T_{\triangle B L E}$ 2.-Character of Piedmont Plateau river waters of south Atlantic coast.

[Analysts, R. B. Dole, W. D. Collins, and Chase Palmer.]

\begin{tabular}{|c|c|c|c|c|c|c|c|c|c|c|c|c|c|c|c|c|c|c|c|}
\hline & \multicolumn{2}{|c|}{ James at Richmond, va. } & \multicolumn{2}{|c|}{ Roanoke at Randolph, Va. } & \multicolumn{2}{|c|}{ Dan at South Boston, $\mathrm{V}_{\mathrm{a}}$} & \multicolumn{2}{|c|}{ Neuse at Raleigh, N. c. } & \multicolumn{2}{|c|}{ Pedee at Pedee, N. C. } & \multicolumn{2}{|c|}{ Wateree at Camden, s. c. } & \multicolumn{2}{|c|}{ Savannah at Augusta, Ga. } & \multicolumn{2}{|c|}{ Oconee at Dublin, Ga. } & \multicolumn{2}{|c|}{ Ocmulgee at Macon, Ga. } & \\
\hline \multirow[t]{2}{*}{$\begin{array}{l}\text { Properties. } \\
\text { Primary salinity........... } \\
\text { Primary alkalinity......... } \\
\text { Secondary alkalinity....... }\end{array}$} & \multicolumn{2}{|c|}{$\begin{array}{c}\text { Per cent. } \\
18.3 \\
4.7 \\
77.0 \\
\end{array}$} & \multicolumn{2}{|c|}{$\begin{array}{r}\text { Per cent. } \\
15.1 \\
8.7 \\
76.2 \\
\end{array}$} & \multicolumn{2}{|c|}{ 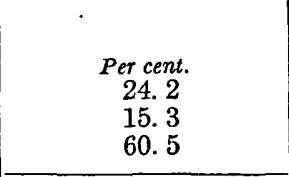 } & \multicolumn{2}{|c|}{ 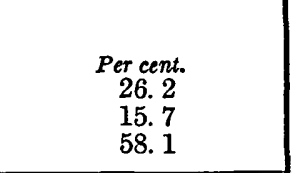 } & \multicolumn{2}{|c|}{$\begin{array}{r}\text { Per cent. } \\
19.2 \\
25.0 \\
55.8 \\
\end{array}$} & \multicolumn{2}{|c|}{$\begin{array}{r}\text { Per cent. } \\
19.8 \\
23.4 \\
56.8 \\
\end{array}$} & \multicolumn{2}{|c|}{$\begin{array}{l}\text { Per cent. } \\
23.0 \\
18.5 \\
58.5\end{array}$} & \multicolumn{2}{|c|}{$\begin{array}{l}\text { Per cent. } \\
25.6 \\
15.2 \\
59.2\end{array}$} & \multicolumn{2}{|c|}{$\begin{array}{l}\text { Per cent. } \\
26.2 \\
16.4 \\
57.4\end{array}$} & \multirow[t]{3}{*}{\begin{tabular}{l}
\multicolumn{1}{c}{ Properties. } \\
Primary salinity. \\
Primary alkalinity. \\
Secondary alkalinity.
\end{tabular}} \\
\hline & \multicolumn{2}{|c|}{100.0} & \multicolumn{2}{|c|}{100.0} & \multicolumn{2}{|c|}{100.0} & \multicolumn{2}{|c|}{100.0} & \multicolumn{2}{|c|}{100.0} & \multicolumn{2}{|c|}{100.0} & \multicolumn{2}{|c|}{100.0} & \multicolumn{2}{|c|}{100.0} & \multicolumn{2}{|c|}{100.0} & \\
\hline $\begin{array}{l}\text { Groups: } \\
\text { Alkalies....... } \\
\text { Earths......... } \\
\text { Strong acids... } \\
\text { Weak acids... }\end{array}$ & $\begin{array}{r}\text { Per cent. } \\
11.52 \\
38.48 \\
9.16 \\
40.84 \\
\end{array}$ & $\begin{array}{r}\text { Mg. per liter. } \\
0.280 \\
.936 \\
.223 \\
.993 \\
\end{array}$ & $\begin{array}{r}\text { Per cent. } \\
11.87 \\
38.13 \\
7.54 \\
42.46 \\
\end{array}$ & $\begin{array}{r}\text { Mg. per liter. } \\
0.244 \\
.784 \\
.155 \\
.873 \\
\end{array}$ & $\begin{array}{r}\text { Per cent. } \\
19.73 \\
30.27 \\
12.07 \\
37.93 \\
\end{array}$ & $\begin{array}{r}\text { Mg.per liter. } \\
0.283 \\
.434 \\
.174 \\
.543\end{array}$ & $\begin{array}{l}\text { Per cent. } \\
20.94 \\
29.06 \\
13.11 \\
36.89\end{array}$ & $\begin{array}{r}\text { Mg. per liter. } \\
0.332 \\
.461 \\
.208 \\
.585\end{array}$ & $\begin{array}{r}\text { Per cent. } \\
22.09 \\
27.91 \\
9.61 \\
40.39\end{array}$ & $\begin{array}{r}\text { Mg. per itier. } \\
0.363 \\
.459 \\
.158 \\
.664 \\
.664\end{array}$ & $\begin{aligned} \text { Per cent. } \\
21.62 \\
28.38 \\
9.91 \\
40.09\end{aligned}$ & $\mid \begin{array}{r}\text { Mg. per iticr. } \\
0.349 \\
\quad .458 \\
.160 \\
.647 \\
.647\end{array}$ & $\begin{array}{r}\text { Per cent. } \\
30.75 \\
19.25 \\
11.50 \\
38.50\end{array}$ & $\begin{array}{r}\text { g. per ilter. } \\
0.5000 \\
.313 \\
.187 \\
.626\end{array}$ & $\begin{array}{r}\text { Per cent. } \\
20.40 \\
29.60 \\
12.80 \\
37.20\end{array}$ & $\left|\begin{array}{r}\text { Sg. per liter. } \\
0.369 \\
.534 \\
.231 \\
.672\end{array}\right|$ & $\begin{array}{r}\text { Per cent. } \\
21.28 \\
28.72 \\
13.07 \\
36.93\end{array}$ & $\mid \begin{array}{r}\text { Arg. per liter. } \\
0.337 \\
.455 \\
.207 \\
.585\end{array}$ & \\
\hline Concentration value. & 100.0 & 2. 432 & 100.0 & 2.056 & 100.0 & 1.434 & 100.0 & 1.586 & 100.0 & 1.644 & 100.0 & 1.614 & 100.0 & 1.626 & 100.0 & 1.806 & 100.0 & 1.584 & Concentration value. \\
\hline 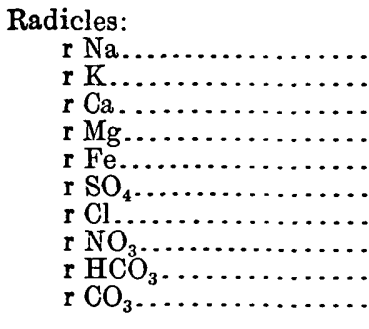 & $\begin{array}{r}\text { Formula. } \\
10.37 \\
1.15 \\
28.33 \\
9.45 \\
.70 \\
6.17 \\
2.79 \\
.20 \\
40.84 \\
.0\end{array}$ & \begin{tabular}{|c|} 
Mg. per liter. \\
0.252 \\
.028 \\
.659 \\
.230 \\
.017 \\
.150 \\
.068 \\
.005 \\
.993 \\
.0 \\
\end{tabular} & $\begin{array}{r}\text { Formula. } \\
10.51 \\
1.36 \\
22.86 \\
13.62 \\
1.65 \\
4.52 \\
2.63 \\
.39 \\
42.46 \\
.0\end{array}$ & \begin{tabular}{|c|} 
Mg. per ititer. \\
0.216 \\
.028 \\
.470 \\
.280 \\
.034 \\
.093 \\
.054 \\
.008 \\
.873 \\
.0 \\
\end{tabular} & $\begin{array}{r}\text { Formula. } \\
17.43 \\
2.30 \\
19.32 \\
8.23 \\
2.72 \\
5.02 \\
6.35 \\
.70 \\
37.93 \\
.0\end{array}$ & \begin{tabular}{|c|} 
Mg. per liter. \\
0.250 \\
.033 \\
.277 \\
.118 \\
.039 \\
.072 \\
.092 \\
.010 \\
.543 \\
.0 \\
\end{tabular} & $\begin{array}{r}\text { Formula. } \\
18.79 \\
2.15 \\
17.84 \\
8.13 \\
3.09 \\
4.73 \\
8.07 \\
.31 \\
36.89 \\
.0\end{array}$ & \begin{tabular}{|r|} 
Mg. per liter. \\
0.298 \\
.034 \\
.283 \\
.129 \\
.049 \\
.075 \\
.128 \\
.005 \\
.585 \\
.0 \\
\end{tabular} & $\begin{array}{r}\text { Formula. } \\
19.29 \\
2.80 \\
18.00 \\
8.70 \\
1.21 \\
5.17 \\
3.77 \\
.67 \\
40.39 \\
.0 \\
\end{array}$ & \begin{tabular}{|c|} 
Mg. per liter. \\
0.317 \\
.046 \\
.296 \\
.143 \\
.020 \\
.085 \\
.062 \\
.011 \\
.664 \\
.0 \\
\end{tabular} & $\begin{array}{c}\text { Formula. } \\
19.08 \\
2.54 \\
17.16 \\
10.97 \\
.25 \\
5.51 \\
4.03 \\
.37 \\
40.09 \\
.0\end{array}$ & \begin{tabular}{|c|} 
Mg. per liter. \\
0.308 \\
.041 \\
.277 \\
.177 \\
.004 \\
.089 \\
.065 \\
.006 \\
.647 \\
.0
\end{tabular} & $\begin{array}{r}\text { Formula. } \\
26.32 \\
4.43 \\
15.31 \\
1.54 \\
2.40 \\
7.75 \\
2.95 \\
.80 \\
31.55 \\
6.95\end{array}$ & \begin{tabular}{|r|} 
Mg. per itier. \\
0.428 \\
.072 \\
.249 \\
.025 \\
.039 \\
.126 \\
.048 \\
.013 \\
.513 \\
.113 \\
\end{tabular} & $\begin{array}{r}\text { Formula. } \\
16.63 \\
3.77 \\
19.90 \\
8.20 \\
1.50 \\
7.15 \\
4.21 \\
1.44 \\
37.20 \\
.0 \\
\end{array}$ & \begin{tabular}{|r|} 
Mg. per liter. \\
0.300 \\
.069 \\
.359 \\
.148 \\
.027 \\
.129 \\
.076 \\
.026 \\
.672 \\
.0
\end{tabular} & \begin{tabular}{|c|} 
Formula. \\
18.31 \\
2.97 \\
17.24 \\
9.72 \\
1.76 \\
6.63 \\
5.62 \\
.82 \\
36.93 \\
.0 \\
\end{tabular} & \begin{tabular}{|r|} 
Mg. per liter. \\
0.290 \\
.047 \\
.273 \\
.154 \\
.028 \\
.105 \\
.089 \\
.013 \\
.585 \\
.0
\end{tabular} & $\begin{array}{c}\text { Radicles: } \\
\text { r Na. } \\
\text { r K. } \\
\text { r Ca. } \\
\text { r Mg. } \\
\text { r Fe. } \\
\text { r SO. } \\
\text { r } \mathrm{Cl}_{4} . \\
\text { r NO } \mathrm{NO}_{3 .} . \\
\text { r HCO } . \\
\text { r } \mathrm{CO}_{3} .\end{array}$ \\
\hline Concentration value & 100.0 & 2.432 & 100.0 & 2.056 & 100.0 & 1.434 & 100.0 & 1. 586 & 100.0 & 1.644 & 100.0 & 1.614 & 100.0 & 1.626 & 100.0 & 1.806 & 100.0 & 1.584 & Concentration value. \\
\hline 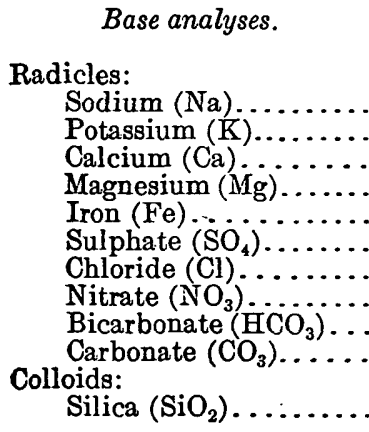 & & $\begin{array}{l}r \text { million. } \\
.9 \\
.1 \\
4.0 \\
.0 \\
.5 \\
.1 \\
.3 \\
.3 \\
0.0 \\
.0 \\
8.0\end{array}$ & Parts & $\begin{array}{l}7 \text { million. } \\
5.0 \\
1.1 \\
9.5 \\
.95 \\
4.4 \\
.2 \\
.5 \\
3.0 \\
.0 \\
1.0\end{array}$ & & $\begin{array}{l}\text { or million. } \\
5.8 \\
1.3 \\
5.6 \\
1.5 \\
1.1 \\
3.4 \\
3.2 \\
1.1 \\
3.0 \\
.0 \\
4.0\end{array}$ & Parts pe, & $\begin{array}{l}7 \text { million. } \\
7.0 \\
.3 \\
5.9 \\
1.4 \\
3.4 \\
4.4 \\
.3 \\
5.0 \\
.0 \\
6.0\end{array}$ & $\begin{array}{r}\text { Parts per } \\
7 \\
1 \\
6 \\
1 \\
4 \\
4 \\
2 \\
40 \\
\\
28\end{array}$ & $\begin{array}{l}7 \text { million. } \\
.4 \\
.8 \\
.1 \\
.9 \\
.0 \\
.0 \\
.7 \\
.0 \\
.0 \\
8.0\end{array}$ & $\begin{array}{r}\text { Parts per } \\
7 \\
1 \\
5 \\
2 \\
4 \\
4 \\
2 \\
39 \\
\\
27\end{array}$ & $\begin{array}{l}\text { er million. } \\
7.2 \\
1.6 \\
.5 \\
2.3 \\
4.2 \\
4.2 \\
.38 \\
9.0 \\
.0 \\
7.0\end{array}$ & $\begin{array}{r}\text { Parts pe } \\
2 \\
3 \\
3 \\
3 \\
2\end{array}$ & $\begin{array}{l}\text { million. } \\
.8 \\
.1 \\
.4 \\
.1 \\
.0 \\
.6 \\
.8 \\
.0 \\
3.4 \\
1.0\end{array}$ & & $\begin{array}{l}\text { frillion. } \\
6.9 \\
.6 \\
7.2 \\
.8 \\
.75 \\
6.2 \\
.7 \\
1.6 \\
.0 \\
.0 \\
6.0\end{array}$ & $\begin{array}{r}\text { Parls per } \\
6 \\
1 \\
5 \\
2 \\
4 \\
4 \\
3 \\
35 \\
\\
26\end{array}$ & $\begin{array}{l}6.8 \text { milion. } \\
.9 \\
.9 \\
.1 \\
.8 \\
.9 \\
.0 \\
.8 \\
.0 \\
.0 \\
6.0\end{array}$ & \begin{tabular}{|c} 
Base analyses. \\
Radicles: \\
Sodium (Na). \\
Potassium (K). \\
Calcium (Ca). \\
Magnesium (Mg). \\
Iron ( $\mathrm{Fe})$. \\
Sulphate $\left(\mathrm{SO}_{4}\right)$. \\
Chloride $(\mathrm{Cl})$. \\
Nitrate $\left(\mathrm{NO}_{3}\right)$. \\
Bicarbonate $\left(\mathrm{HCO}_{3}\right)$. \\
Carbonate $\left(\mathrm{CO}_{3}\right)$. \\
Colloids: \\
Silica $\left(\mathrm{SiO}_{2}\right)$.
\end{tabular} \\
\hline $\begin{array}{l}\text { Total dissolved solids } \\
\text { Number of composites...... } \\
\text { Dates........................... }\end{array}$ & $\begin{array}{r}3 \\
\text { Sept. 17, } \\
22,1907\end{array}$ & $\begin{array}{l}1.7 \\
6.0 \\
1906-\text { Sept. }\end{array}$ & $\begin{array}{l}\text { Sept. } 7^{2}, \\
12,190\end{array}$ & $\begin{array}{l}4.1 \\
0.0 \\
1906-\text { May }\end{array}$ & $\begin{array}{r}\text { Sept. }{ }^{2} \\
2,1907 .\end{array}$ & $\begin{array}{l}3.2 \\
1.0 \\
1.906-\text { May }\end{array}$ & Apr. $1-0$ & $\begin{array}{l}8.7 \\
8.0 \\
\text { ct. } 1,1907 .\end{array}$ & $\begin{array}{r}72 \\
10 \\
\text { May 2-Oc }\end{array}$ & $\begin{array}{l}2.2 \\
0.0 \\
i .19,1907 .\end{array}$ & $\begin{array}{r}69 \\
15 \\
\text { May 10-0c }\end{array}$ & $\begin{array}{l}9.8 \\
5.0 \\
\text { ct. } 25,1907 .\end{array}$ & $\begin{array}{r}6 \\
1 \\
\text { May 12-0 }\end{array}$ & $\begin{array}{l}.3 \\
.0 \\
2 t .22,1907 .\end{array}$ & May $15-0$ & $\begin{array}{l}5.9 \\
4.0 \\
\text { ct. } 17,1907 .\end{array}$ & May 7-Oct & $\begin{array}{l}9.2 \\
4.0 \\
\text { t. } 21,1907 .\end{array}$ & $\begin{array}{l}\quad \begin{array}{l}\text { Total d i s } \mathrm{s} 0 \mathrm{l} \text { v e d } \\
\text { olids. }\end{array} \\
\text { Number of composites. } \\
\text { Dates. }\end{array}$ \\
\hline
\end{tabular}

95451ํ-Bull. 479-11. (To face page 16.) 
TABLE 3.-Character of Coastal Plain river waters entering eastern Gulf of Mexico.

[Analysts, R. B. Dole, W. D. Collins, and Chase Palmer.]

\begin{tabular}{|c|c|c|c|c|c|c|c|c|c|c|}
\hline & \multicolumn{2}{|c|}{$\begin{array}{c}\text { Oostanaula at } \\
\text { Rome, Ga. }\end{array}$} & \multicolumn{2}{|c|}{$\begin{array}{l}\text { Alabama at } \\
\text { Selma, Ala. }\end{array}$} & \multicolumn{2}{|c|}{$\begin{array}{l}\text { Cahaba at Bir- } \\
\text { mingham, Ala. }\end{array}$} & \multicolumn{2}{|c|}{$\begin{array}{c}\text { Tombigbee at } \\
\text { Epes, Ala. }\end{array}$} & \multicolumn{2}{|c|}{$\begin{array}{l}\text { Pearl at Jack- } \\
\text { son,_Miss. }\end{array}$} \\
\hline $\begin{array}{l}\text { Properties. } \\
\text { Primary salinity.... } \\
\text { Primary alkalinity.. } \\
\text { Secondary alkalinity }\end{array}$ & \multicolumn{2}{|c|}{$\begin{array}{r}\text { Per cent. } \\
10.2 \\
20.3 \\
69.5 \\
\end{array}$} & \multicolumn{2}{|c|}{$\begin{array}{c}\text { Per cent. } \\
15.1 \\
10.6 \\
74.3 \\
\end{array}$} & \multicolumn{2}{|c|}{$\begin{array}{l}\text { Per cent. } \\
20.4 \\
4.6 \\
75.0\end{array}$} & \multicolumn{2}{|c|}{$\begin{array}{c}\text { Per cent. } \\
15.4 \\
11.6 \\
73.0\end{array}$} & \multicolumn{2}{|c|}{$\begin{array}{l}\text { Per cent. } \\
28.1 \\
14.5 \\
57.4\end{array}$} \\
\hline & \multicolumn{2}{|c|}{100.0} & \multicolumn{2}{|c|}{100.0} & \multicolumn{2}{|c|}{100.0} & \multicolumn{2}{|c|}{100.0} & \multicolumn{2}{|c|}{100.0} \\
\hline $\begin{array}{l}\text { Reacting values. } \\
\text { Groups: } \\
\text { Alkalies............. } \\
\text { Earths............ } \\
\text { Strong acids....... } \\
\text { Weak acids....... }\end{array}$ & \begin{tabular}{|c} 
Per \\
cent. \\
15.23 \\
34.77 \\
5.10 \\
44.90
\end{tabular} & $\begin{array}{c}\text { Mg. per } \\
\text { liter. } \\
0.391 \\
.893 \\
.131 \\
1.153\end{array}$ & \begin{tabular}{|c|} 
Per \\
cent. \\
12.87 \\
37.13 \\
7.58 \\
42.42
\end{tabular} & \begin{tabular}{|c} 
Mg. per \\
liter. \\
0.314 \\
.900 \\
.185 \\
1.035
\end{tabular} & \begin{tabular}{|c|} 
Per \\
cent. \\
12.48 \\
37.52 \\
10.19 \\
39.81
\end{tabular} & $\begin{array}{r}\text { Mg. per } \\
\text { liter. } \\
0.327 \\
.983 \\
.267 \\
1.043\end{array}$ & $\begin{array}{c}\text { Per } \\
\text { cent. } \\
13.47 \\
36.53 \\
7.69 \\
42.31\end{array}$ & $\begin{array}{c}\text { Mg. per } \\
\text { liter. } \\
0.403 \\
1.093 \\
.230 \\
1.266\end{array}$ & \begin{tabular}{|c|} 
Per \\
cent. \\
21.32 \\
28.68 \\
14.08 \\
35.92
\end{tabular} & $\begin{array}{c}\text { Mg.per } \\
\text { liter. } \\
0.365 \\
.491 \\
.241 \\
.615\end{array}$ \\
\hline $\begin{array}{r}\text { Concentratio } n \\
\text { value................. }\end{array}$ & 100.0 & 2. 568 & 100.0 & 2.440 & 100.0 & 2.620 & 100.0 & 2.992 & 100.0 & 1.712 \\
\hline 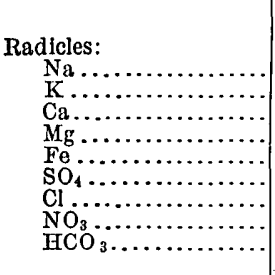 & $\begin{array}{r}\text { For- } \\
\text { mula. } \\
13.94 \\
1.29 \\
21.81 \\
12.26 \\
.70 \\
.73 \\
1.60 \\
.35 \\
44.90 \\
\end{array}$ & $\begin{array}{c}\text { Mg. per } \\
\text { liter. } \\
0.358 \\
.033 \\
.560 \\
.315 \\
.018 \\
.081 \\
.041 \\
.009 \\
1.153 \\
\end{array}$ & $\begin{array}{c}\text { For- } \\
\text { mula. } \\
10.98 \\
1.89 \\
25.86 \\
11.23 \\
.04 \\
4.01 \\
2.91 \\
.66 \\
42.42 \\
\end{array}$ & $\begin{array}{c}\text { Mg. per } \\
\text { liter } \\
0.268 \\
.046 \\
.631 \\
.274 \\
.001 \\
.098 \\
.071 \\
.016 \\
1.035 \\
\end{array}$ & \begin{tabular}{|c|} 
For- \\
mula. \\
10.34 \\
2.14 \\
26.45 \\
10.57 \\
.50 \\
7.06 \\
2.71 \\
.42 \\
39.81
\end{tabular} & $\mid \begin{array}{c}\text { Mg.per } \\
\text { liter. } \\
0.271 \\
.056 \\
.693 \\
.277 \\
.013 \\
.185 \\
.071 \\
.011 \\
1.043\end{array}$ & $\begin{array}{r}\text { For- } \\
\text { mula } \\
11.57 \\
1.90 \\
32.68 \\
2.98 \\
.87 \\
4.55 \\
2.67 \\
.47 \\
42.31\end{array}$ & $\begin{array}{c}\text { Mg.per } \\
\text { liter. } \\
0.346 \\
.057 \\
.978 \\
.089 \\
.026 \\
.136 \\
.080 \\
.014 \\
1.266\end{array}$ & \begin{tabular}{|c|} 
For- \\
mula. \\
18.34 \\
2.98 \\
21.68 \\
6.36 \\
.64 \\
7.89 \\
5.43 \\
.76 \\
35.92
\end{tabular} & $\begin{array}{r}\text { Mg.per } \\
\text { liter. } \\
0.314 \\
.051 \\
.371 \\
.109 \\
.011 \\
.135 \\
.093 \\
.013 \\
.015\end{array}$ \\
\hline $\begin{array}{r}\text { Con centration } \\
\text { value............... }\end{array}$ & 100.0 & 2.568 & 100.0 & 2.440 & 100.0 & 2.620 & 100.0 & 2. 992 & 100.0 & 1.712 \\
\hline 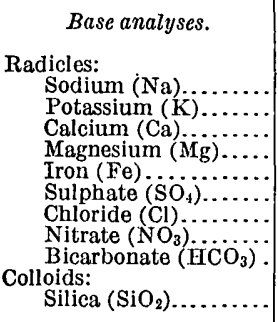 & \multicolumn{2}{|c|}{$\begin{array}{c}\text { Parts per mil- } \\
\text { lion. } \\
8.1 \\
1.4 \\
11.0 \\
3.6 \\
.5 \\
4.1 \\
1.6 \\
.56 \\
71.0 \\
29.0 \\
\end{array}$} & $\begin{array}{r}\text { Parts } \\
\quad \text { li }\end{array}$ & $\begin{array}{l}\text { per mil- } \\
\text { on. } \\
6.4 \\
1.9 \\
13.0 \\
3.7 \\
.02 \\
4.5 \\
2.3 \\
1.0 \\
2.0 \\
15.0\end{array}$ & $\begin{array}{r}\text { Parts } \\
\quad \text { lic }\end{array}$ & $\begin{array}{l}\text { per mil- } \\
\text { on. } \\
6.3 \\
2.2 \\
4.0 \\
3.5 \\
.37 \\
8.8 \\
2.4 \\
.7 \\
.7 \\
6.0 \\
6.0\end{array}$ & $\begin{array}{r}\text { Parts } \\
\quad \text { lid }\end{array}$ & $\begin{array}{l}\text { per mil- } \\
\text { on. } \\
8.2 \\
2.4 \\
0.0 \\
1.5 \\
.75 \\
6.3 \\
2.6 \\
.9 \\
6.0 \\
3.0\end{array}$ & $\begin{array}{r}\text { Parts } \\
\text { lic }\end{array}$ & $\begin{array}{l}\text { per mil- } \\
\text { ion. } \\
7.3 \\
2.0 \\
7.6 \\
1.5 \\
.33 \\
6.4 \\
3.2 \\
.74 \\
37.0 \\
14.0\end{array}$ \\
\hline 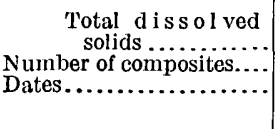 & $\begin{array}{r}10 \\
1 \\
\text { May } 3- \\
19\end{array}$ & $\begin{array}{l}33.0 \\
12.0 \\
\text {-Oct. } 28, \\
07 .\end{array}$ & Sept. & $\begin{array}{l}6.0 \\
4.0 \\
\text { 4-Oct. } \\
1907 .\end{array}$ & $\begin{array}{r}8 \\
1 \\
\text { May } 5 \\
19\end{array}$ & $\begin{array}{l}\text { S9. } \\
4.0 \\
\text {-Nov. 1, } \\
07 .\end{array}$ & $\begin{array}{r}10 \\
1 \\
\text { May } 14 \\
19\end{array}$ & $\begin{array}{l}1.0 \\
4.0 \\
\text {-Oct.24, } \\
07 .\end{array}$ & $\begin{array}{r}5 \\
\text { May } 10 \\
19\end{array}$ & $\begin{array}{l}59.0 \\
.15 \\
\text {-OCct.19, } \\
07 .\end{array}$ \\
\hline
\end{tabular}

During the period of the investigation the waters in general were soft and all were characterized by primary alkalinity, by which their softness is maintained. It is true that they contain dissolved mineral substances in small quantities, but the carbonates of the alkalies are perceptibly in excess of the amounts necessary to precipitate the other bases, so that permanent hardness is impossible. Here, then, is a large section of the country favored with running waters whose incrusting constituents can not form hard scale in boilers and whose alkalies are sufficiently in excess to keep them soft. An 
idea of the excessive alkalinity of these waters can be obtained by expressing their primary alkalinity in terms of sodium carbonate, as was done in considering the waters of Lake Champlain (pp. 9-10). An estimate made in this way shows that the quantity of sodium, reckoned as sodium carbonate-that is, that quantity of sodium in excess of all that can be regarded as equivalent to the sulphates, chlorides, and nitrates annually discharged by the rivers within the area extending from the James to and including the Pearl-is enormous. The calculated quantity of sodium carbonate annually discharged from this area into the Atlantic Ocean and Gulf of Mexico is no less than $2,693,000$ tons.

The quantity of alkaline material conveyed by these rivers to the sea is very large compared with the quantity produced commercially. In 1904, for example, 63 establishments in the United States produced 734,209 tons of sodas of all kinds, namely, sodium carbonate, sodium bicarbonate, caustic soda, and sal soda; and 11,511 tons of soda were imported, a total of 754,720 tons, valued at $\$ 13,579,080$.

\section{RELATION OF WATER PROPERTIES TO GEOLOGIC FORMATIONS.}

The result of a mineral analysis of the water of a river may serve as an index of the character of the geologic formations in its drainage basin, if the analyses are expressed, not in amounts of the radicles found in the water, but in terms showing the properties acquired by the water as it passes over or through the rocks.

The waters of Dan, Roanoke, James, and Shenandoah rivers, all originating among the Appalachian Mountains of western Virginia, develop markedly different qualities, as shown by the complete analyses given in Tables 1 and 2 . The reaction properties of these waters, as deduced from analyses made of samples collected at points many miles distant from the sources of the rivers, are stated in percentage degrets in the following table:

Reaction properties of waters of Dan, Roanoke, James, and Shenandoah rivers.

\begin{tabular}{|c|c|c|c|c|}
\hline$\cdot$ & Dan. & Roanoke & James. & $\begin{array}{l}\text { Shenan- } \\
\text { doah. }\end{array}$ \\
\hline $\begin{array}{l}\text { Primary salinity } \ldots \ldots \ldots \ldots \ldots \ldots \\
\text { Secondary salinity } \ldots \ldots \ldots \ldots \ldots \ldots \\
\text { Primary alkalinity } \ldots \ldots \ldots \ldots \ldots \ldots \\
\text { Secondary alkalinity } \ldots \ldots \ldots \ldots \ldots\end{array}$ & $\begin{array}{r}24.2 \\
.0 \\
15.3 \\
60.5\end{array}$ & $\begin{array}{r}15.1 \\
.0 \\
8.7 \\
76.2\end{array}$ & $\begin{array}{r}18.3 \\
.0 \\
4.7 \\
77.0\end{array}$ & $\begin{array}{r}10.5 \\
.2 \\
.0 \\
89.3\end{array}$ \\
\hline & 100.0 & 100.0 & 100.0 & 100.0 \\
\hline
\end{tabular}

These figures show a progressive decline northward in the proportion of primary alkalinity, that is, permanent alkalinity, or such alkalinity as would be caused by alkaline carbonates and alkaline 
bicarbonates $\left(\mathrm{Na}_{2} \mathrm{CO}_{3}\right.$ and $\left.\mathrm{NaHCO}_{3}\right)$, and in the water of Shenandoah River this property is entirely wanting. Equally striking is the progressive advance in secondary alkalinity-that is, the property caused by alkaline earth bicarbonates, $\mathrm{CaH}_{2}\left(\mathrm{CO}_{3}\right)_{2}$ and $\mathrm{MgH}_{2}\left(\mathrm{CO}_{3}\right)_{2}$. This property coincides with temporary hardness.

Primary salinity-that is, salinity caused by the sulphates and chlorides of the alkalies-is also a conspicuous property of all these waters, ranging between 10 and 24 per cent of the total properties represented. The prominence of primary salinity among the properties of all these waters and its capacity for independent variation suggest that the cause of the progressive variations in the proportions of the two kinds of alkalinity may be found in the chemical nature of the rocks.

All these rivers, except the Dan, rise in the Appalachian Valley, between the Blue Ridge and the Alleghenies, and start with waters probably of the same general character. The headwaters of the Dan are not strictly within the Appalachian Valley, for the river rises on the eastern slope of the Blue Ridge. It flows eastward in a drainage basin comprising 2,700 square miles, which is practically confined to the granitic area of the Piedmont Plateau. The water was sampled for analysis at South Boston, Va., about 137 miles from the source of the river. The Dan is essentially a primary stream in that its waters derive their soluble substances from decomposed igneous rocks. Its water, like that of many other rivers that flow in areas of crystalline granitic rocks, is high in primary alkalinity.

The Shenandoah, about 120 miles in length, rises in Augusta County, Va., about 25 miles north of Balcony Falls, on James River, flows northeastward in the valley west of the Blue Ridge, and discharges into the Potomac at Harpers Ferry. The properties of its water are directly due to the soluble material received from siliceous limestones and shales. The entire valley is underlain by limestones, the shales outcropping at the base of the mountains. The virtual absence of permanent hardness ( 0.2 per cent) of the waters near the mouth of the river and the comparatively low primary salinity are characteristic of waters that traverse ancient limestone areas. Shenandoah Valley, lying well south of the region covered by glacial drift, occupies a geographical position favorable for observing the character that a river water acquires directly from the local formations. It is to be observed that the hardness of the Shenandoah River water is alkalinity; its alkalinity is hardness. Alkalinity and hardness are coincident in but few river waters.

Roanoke River rises in the Appalachian Valley in Montgomery County, Va., flows eastward about 50 miles, traversing the same limestone formations which are crossed by James River a few miles 
farther north and in which the Shenandoah remains through its entire course; it then cuts through the Blue Ridge and emerges on the granitic area of the Piedmont Plateau there to continue its eastward journey. The distance from the Blue Ridge to the sampling

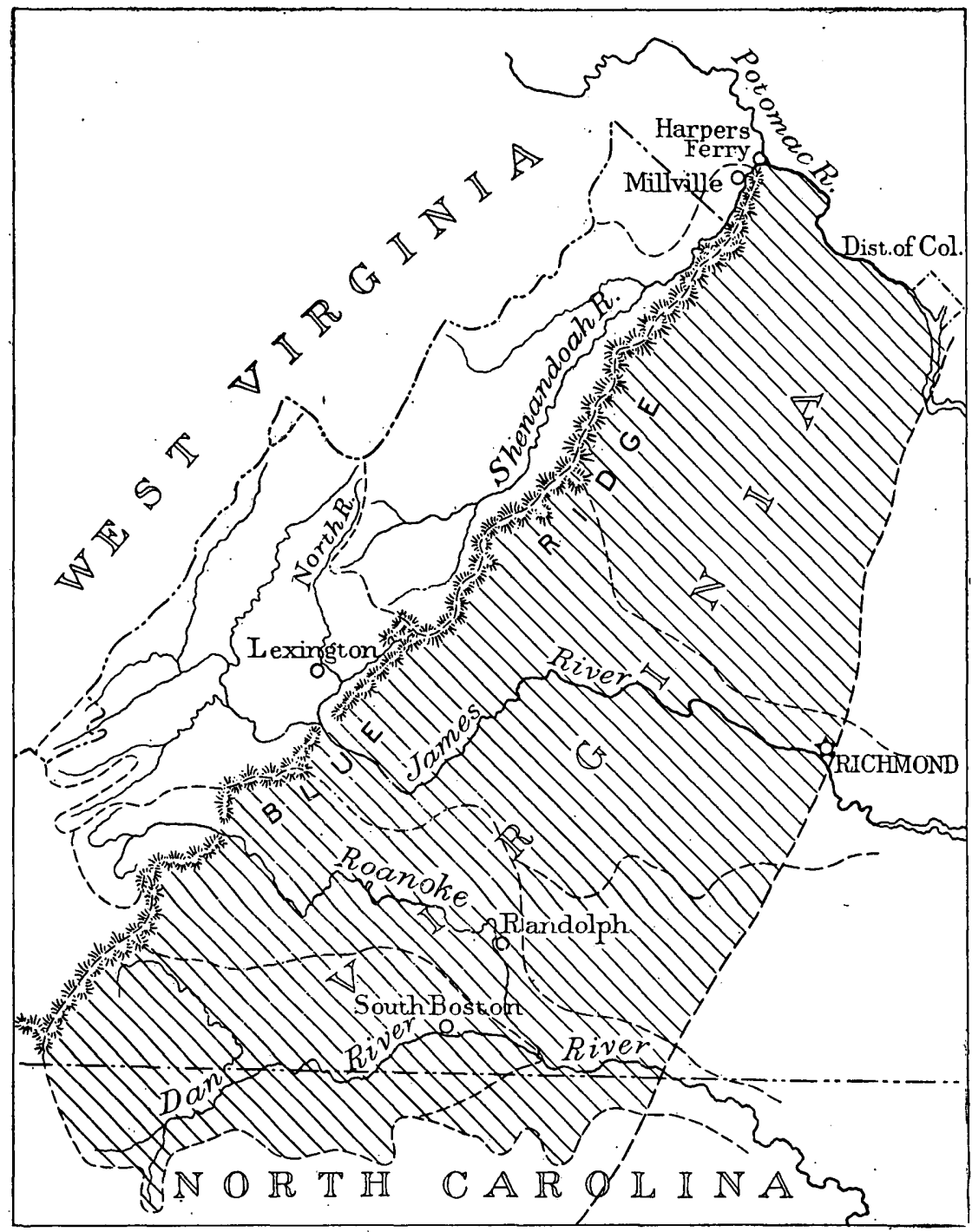

FIGURE 1.-Map showing geologic character of the drainage basins of Shenandoah, James, Roanoke, and Dan rivers. The shaded portion represents the area of crystalline rocks; the uns.laded portion, sedimentary rocks. Dash lines represent limits of drainage basins.

station at Randolph, Va., is a little less than 100 miles. The reaction properties of the river water at Randolph may be regarded as typical of a river water beginning in sedimentary formations and subsequently modified by the addition of water from a granitic area. 
In comparing the properties of this water with the properties of the waters of the adjacent streams, it should be remembered that the Roanoke flows in an area of sedimentary rocks for about one-third of its course and in an area of granitic rocks for about two-thirds of its course. The drainage area of Roanoke River is very unequally divided between the two geologic districts through which it flows. The portion within the limestone area west of the Blue Ridge comprises about 583 square miles, constituting only about one-fifth of the area of its entire basin; the portion on the Piedmont Plateau comprises about 3,080 square miles, or about four-fifths of the entire area from. which the water of the Roanoke has acquired its properties.

James River drains an area about equally divided between the Appalachian Valley and the Piedmont Plateau, the upper part, lying west of the Blue Ridge, embracing 3,030 square miles, and the Piedmont district about 3,800 square miles. Moreover, the James receives in the area of sedimentary formations contributions from several rivers of considerable size. Except for a few good analyses of waters in Rockbridge County, Va., made by A. W. White, ${ }^{1}$ no information concerning the composition of these mountain streams is available. Three of White's analyses, interpreted according to the plan here adopted, show the general character of the waters received by the James just before it leaves the region of sedimentary rocks.

\section{Analyses of waters flowing into James River.}

[Partis per million.]

1. Moore's Spring, North River drainage basin, near Lexington. Described as flowing from pure limestone.

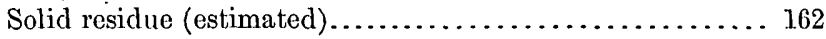

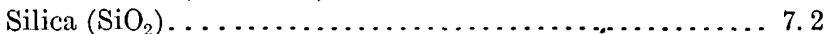

2. South River, tributary to North River. Described as flowing along the dividing line between the Cambrian limestones and Cambrian sandstones.

Solid residue (estimated) $\ldots \ldots \ldots \ldots \ldots \ldots \ldots \ldots \ldots \ldots \ldots \ldots$

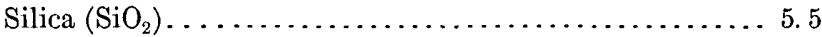

3. North River, tributary to James River. Described as coming chiefly from limestones, sandstones, and shales; sampled above junction with South River.

Solid residue (estimated) $\ldots \ldots \ldots \ldots \ldots \ldots \ldots \ldots \ldots \ldots \ldots .85$

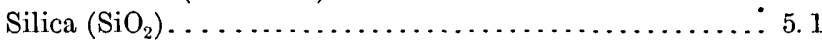

Properties of reaction.

\begin{tabular}{|c|c|c|c|}
\hline & 1 & 2 & 3 \\
\hline \multirow[t]{2}{*}{ 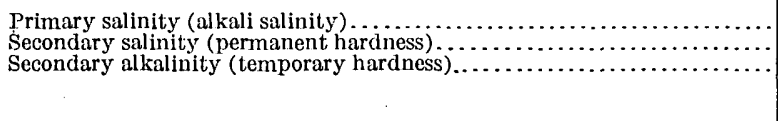 } & $\begin{array}{r}1.84 \\
4.04 \\
94.12\end{array}$ & $\begin{array}{r}4.76 \\
7.38 \\
87.86\end{array}$ & $\begin{array}{r}4.98 \\
10.14 \\
84.88\end{array}$ \\
\hline & 100.0 & 100.0 & 100.0 \\
\hline
\end{tabular}

1 Composition of the waters of Rockbridge County, Va.; thesis for Washington and Lee University, 1906. 
These analyses afford excellent examples of the character of water from calcareousformations. The small proportion of silica reported as dissolved in the waters of James River valley west of the Blue Ridge is noteworthy, because of its marked contrast with the proportion of silica in the water of the James after the river has acquired primary alkalinity from the crystalline siliceous formations of the Piedmont Plateau.

This consideration of the chemical character of the waters of Dan, Roanoke, James, and Shenandoah rivers indicates that the results of water analyses may hereafter prove to be helpful guides in regionsl studies of streams.

\section{SILICA IN RIVER WATERS.}

RELATION OF SILICA TO PRIMARY ALKALINITY.

A high proportion of silica in the mineral content of surface waters is thought by many observers to be normal only to small streams flowing from crystalline siliceous rocks, and especially to those streams near their sources; that is, if silica is a prominent constituent of the inorganic material dissolved in the water of a large stream, its presence must be attributed to some extraneous cause, such as tropical climatic conditions in the drainage basin or abundance of organic matter in the waters. The particular kind of organic matter that is supposed to facilitate the transportation of silica in water is that commonly known as azo-humic acids. Owing to supposed basic properties acquired by the incorporation of nitrogenous material, these azo-humic acids are assumed to be capable of forming with hydrated silicic acid soluble compounds of unknown character, and thus to assist the water to carry along the silica with the rest of the "invisible load." Since high importance has been attached to these assumed azo-humic acids in other geologic phenomena involving chemical processes, it seems not out of place here to state the circumstances under which the term azo-humic acids was introduced to chemical literature.

A report had been read before the French Academy of Sciences of certain elabọrate experiments made by Friedel and Ladenburg ${ }^{1}$ involving the synthesis of a compound of silicon analogous to propionic acid. To that report Paul Thénard ${ }^{2}$ offered remarks, in the course of which he alluded to some observations made by himself on the solution of silica in company with soil acids. He suggested that the solution of the silica might be due to nitrogen in the organic substances, but he cautiously refrained from making a definite statement concerning the nature of the products, merely promising to report in detail the results of subsequent experiments. So far as can be learned the promise was not fulfilled.

I C. Friedel and A. Ladenburg,.Sur l'acide silico-propionique: Compt. Rend., vol. 20, 1870, p. 1407.

2 P. Thénard, Observations sur le mémoire de M. Friedel: Idem, p. 1412. 
The solubility of humic substances in water alone and in alkaline solutions was observed as long ago as 1826 . Sprengel ${ }^{1}$ was the first to recognize in these products of the soil a new class of substances, and his account of humus acid and its salts contains valuable information concerning the chemistry of these colloidal substances.

Directly bearing on the solubility of silicic acid in solutions of the humic substances is Sprengel's observation that silicic acid is precipitated in gelatinous form if solutions of this kind of organic material are added to a solution of potassium silicate. In view of these early observations by Sprengel concerning the action of humic solutions on silicates, and since Thénard himself seems to have considered as premature his announcement of the possible existence of azo-humic acids, it is unnecessary now to consider those vague substances as factors in the solution and portage of silica in river waters.

The solvent action of alkaline carbonates and hydroxides on silica has long been known. Hydrated silicic acid is easily attacked and dissolved, even by dilute solutions of sodium carbonate, and dilute sodium carbonate is the reagent commonly used in the laboratory to separate silicic acid from quartz and refractory silicates. Unless precaution is taken against using an unduly strong solution of the alkaline carbonate, appreciable amounts of quartz are dissolved with the silicic acid and the separation of silicic acid from quartz is frustrated. Quartz is attacked and dissolved by prolonged digestion in even dilute alkaline carbonate solutions. ${ }^{2}$

SILICA IN THE WATERS OF THE PIEDMONT PLATEAU AND COASTAL PLAIN OF THE GULF OF MEXICO.

As silica contributes largely to the weight of the inorganic substances dissolved in the surface waters of the Piedmont Plateau and Coastal Plain area of the Southern States east of the Mississippi, the analyses of the waters of the rivers of this region afford exceptionally favorable data for a comparative study of the proportional amounts of silica with respect to primary alkalinity-a property common to all the waters during the period of the investigation.

The waters of the rivers fall naturally into three groups, according to the geology of the drainage basins:

Group 1. Waters of streams coming from regions of sedimentary rocks and afterward traversing areas of crystalline rocks.

Group 2. Waters of streams practically confined to areas of crystalline rocks.

Group 3. Waters of streams practically confined to areas of sedimentary rocks and alluvial sands and clays.

\footnotetext{
1 Sprengel, C., Ueber Pflanzenhumus, Humussäure und humussaure Salze: Archiv für die gesammte Naturlehre (K. W. G. Kastner), Nürnberg, Band 8, 1826, p. 126-220.

2 Lunge and Millberg, Zeitschrift für angewandte Chemie, 1897, pp. 390 and 425.
} 
Primary alkalinity and silica in Piedmont Plateau and Gulf Coastal Plain waters.

\begin{tabular}{|c|c|c|c|}
\hline . & $\begin{array}{l}\text { Distance } \\
\text { from } \\
\text { source to } \\
\text { sampling } \\
\text { station. }\end{array}$ & $\begin{array}{l}\text { Primary } \\
\text { alkalinity. }\end{array}$ & $\begin{array}{c}\underset{\mathrm{SiO}_{2} \text { in }}{\text { inorganic }} \\
\text { substances. } \\
\\
.\end{array}$ \\
\hline $\begin{array}{l}\text { Group 1: } \\
\text { James.... } \\
\text { Roanoke. }\end{array}$ & $\begin{array}{r}\text { Miles. } \\
276 \\
162\end{array}$ & $\begin{array}{r}\text { Per cent. } \\
4.7 \\
8.7\end{array}$ & $\begin{array}{r}\text { Per cent. } \\
22.0 \\
28.3\end{array}$ \\
\hline $\begin{array}{l}\text { Group 2: } \\
\text { Dan }\end{array}$ & & & \\
\hline $\begin{array}{l}\text { Dan.. } \\
\text { Neuse }\end{array}$ & 137 & 15. 3 & 38.0 \\
\hline $\begin{array}{l}\text { Neuse.. } \\
\text { Pedee.. }\end{array}$ & $\begin{array}{r}72 \\
225\end{array}$ & $\begin{array}{l}15.7 \\
25.0\end{array}$ & $\begin{array}{l}37.8 \\
38.8\end{array}$ \\
\hline Wateree. & 216 & 23.4 & 38.7 \\
\hline Savanna & 168 & 18.5 & 31.2 \\
\hline Oconee... & 176 & 15. 2 & 24.3 \\
\hline Ocmulgee.. & 62 & 16.4 & 32.8 \\
\hline Group 3: & & & \\
\hline Alabama. & 447 & 10.5 & 19. 2 \\
\hline Tombigbee... & 192 & $\begin{array}{r}4.8 \\
11.6\end{array}$ & 22.3 \\
\hline Pearl.. & 120 & 14.5 & 23.0 \\
\hline
\end{tabular}

The acquisition of primary alkalinity by James, Roanoke, and Dan rivers has already been considered in discussing their environment. Equally striking is the proportional increase of silica in the inorganic material contained in their waters. The advance and decline of silica concomitant with the rise and fall in primary alkalinity in all the waters of the Atlantic coast rivers point to a continuance of the. correlation of silica with the primary alkalinity of the river waters, just as silica is associated with the alkalies at the beginning. Although subject to various disturbing influences, the mixed waters of the Gulf Coastal Plain rivers show a similar relation between silica and primary alkalinity. A high proportion of silica in the mineral content of these river waters is easily accounted for, because the acidic radicles of the alkaline carbonates, always present in waters of this character, tend constantly to form the sparingly soluble carbonates of the other positive radicles of the solutes, while the soluble bases of the alkalies from the hydrolyzed alkaline carbonates produce alkaline solutions naturally favorable to the retention of dissolved silica.

OTHER RIVERS DRAINING AREAS OF CRYSTALIINE ROCKS.

OTTAWA RIVER.

The Ottawa is the largest tributary of the St. Lawrence. It rises in latitude $47^{\circ} 53^{\prime}$ north, longitude $75^{\circ} 35^{\prime}$ west, and discharges into St. Lawrence River near Montreal. It is 730 miles long and drains an area comprising more than 56,000 square miles. According to R. A. Daly, geologist of the International Boundary Commission, the Ottawa basin is larger than any other river basin known to be underlain by pre-Cambrian formations. ${ }^{1}$

\footnotetext{
${ }^{1}$ Daly, R. A., First calcareous fossils and the evolution of the limestones: Bull. Geol. Soc. Ámerica, vol. 20, 1909, pp. 153-170.
} 
The composition of the water of Ottawa River at high stages has been recently determined by Frank T. Shutt and A. Gordon Spencer. ${ }^{1}$ The water was collected in July, 1907, from the main stream above Chaudière Falls.

The interpretation of an analysis of Ottawa River water made by $\mathrm{T}$. Sterry Hunt at a much earlier date shows that before the snows begin to melt the proportion of primary alkalinity to the other properties of the water is much higher than it appears to be during the summer floods. The water for Hunt's analysis was collected in March, 1854, at St. Anne's Lock, near Montreal. ${ }^{2}$

These, analyses are interpreted in the following table:

Character cf Ottawa River water interpreted from analyses.

\begin{tabular}{|c|c|c|c|}
\hline & $\begin{array}{l}\text { Analysis } \\
\text { by Shutt } \\
\text { and Spen- } \\
\text { cer. }\end{array}$ & $\begin{array}{l}\text { Analysis } \\
\text { by Hiunt. }\end{array}$ & A verage. \\
\hline \multirow[t]{2}{*}{ 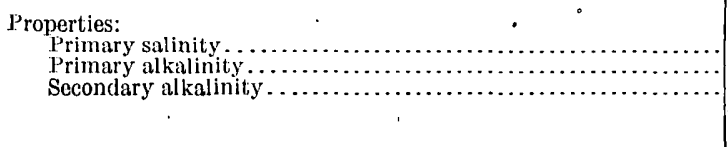 } & $\begin{array}{r}\text { Per cent. } \\
14.7 \\
1.8 \\
83.5\end{array}$ & $\begin{array}{r}\text { Per cent. } \\
8.3 \\
9.8 \\
81.9\end{array}$ & $\begin{array}{r}\text { Per cent. } \\
11.5 \\
5.8 \\
82.7\end{array}$ \\
\hline & 100.0 & 100.0 & 100.0 \\
\hline \multirow[t]{2}{*}{ 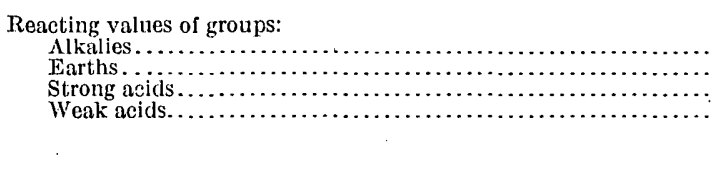 } & $\begin{array}{r}8.23 \\
41.77 \\
72.35 \\
42.65\end{array}$ & $\begin{array}{r}9.03 \\
40.97 \\
4.13 \\
45.87\end{array}$ & $\begin{array}{r}8.63 \\
41.37 \\
5.74 \\
44.26\end{array}$ \\
\hline & 100.0 & 100.0 & 100.0 \\
\hline \multirow[t]{2}{*}{ 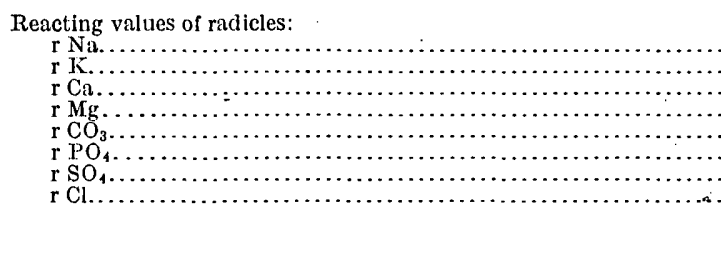 } & $\begin{array}{r}6.77 \\
1.46 \\
28.04 \\
13.73 \\
41.88 \\
.77 \\
6.0 \\
1.35\end{array}$ & \begin{tabular}{r}
6.67 \\
2.36 \\
32.33 \\
8.64 \\
45.77 \\
\hdashline 2.62 \\
1.51
\end{tabular} & 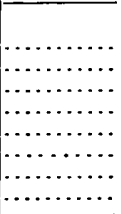 \\
\hline & 100.0 & 100.0 & \\
\hline & $\begin{array}{c}\text { Mg. per } \\
\text { liter. }\end{array}$ & $\begin{array}{l}\text { Mg. per } \\
\text { liter. }\end{array}$ & \\
\hline 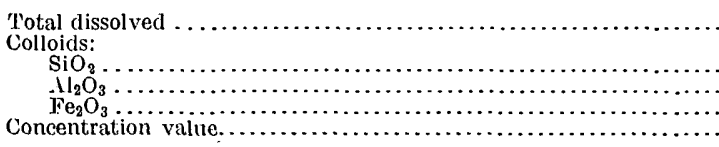 & \begin{tabular}{c|c}
35.1 \\
7.1 \\
.5 \\
.7 \\
1.034
\end{tabular} & $\begin{array}{r}60.0 \\
21.0 \\
\cdots \cdots \ldots . . . \\
1.528\end{array}$ & \\
\hline
\end{tabular}

Attention is called to the high proportion of silica in the mineral content of the water at the time of Hunt's analysis and also to the striking differences in the chemical character of the solutions with respect to the proportions of properties on the two occasions when the water of Ottawa River was investigated. 
MAHANUDDY $\cdot$ RIVER, INDIA, AND URUGUAY RIVER, BRAZL.

Mahanuddy River, of India, is selected to illustrate the chemical character of a river water draining a sparsely settled area. According to Edward Nicholson, the geologic formations in its drainage basin are made up chiefly of trap, basalt, and gneiss, and the soils formed by the decomposition of those rocks. The river is about 500 miles long, and empties into the Bay of Bengal. The drainage basin of Mahanuddy River lies wholly within the Tropics. The analysis interpreted was made by Nicholson ${ }^{1}$ on a sample collected at Cuttack, India, about 60 miles above the mouth of the river.

Uruguay River rises in the mountains of Santa Catharina in southern Brazil, flows first westward and then southward, and empties into the La Plata near Buenos Aires. The Uruguay is about 1,000 miles long. Its water is said to be clear and free from sediment, except during seasons of flood. The high primary alkalinity of the water and the high proportion of silica in the dissolved inorganic material are noteworthy features of this great stream of the South Temperate Zone. The analysis selected for interpretation was made by Kyle, ${ }^{2}$ who was for many years water expert in Argentina.

The character of Mahanuddy and Uruguay rivers, as interpreted from the analyses, is shown in the following table:

Character of Mahanuddy and Uruguay rivers.

\begin{tabular}{|c|c|c|}
\hline & $\begin{array}{l}\text { Mahanuddy } \\
\text { (Nicholson, } \\
\text { analyst). }\end{array}$ & $\begin{array}{c}\text { Uruguay } \\
\text { (Kyle, } \\
\text { 'analyst). }\end{array}$ \\
\hline \multirow[t]{2}{*}{ 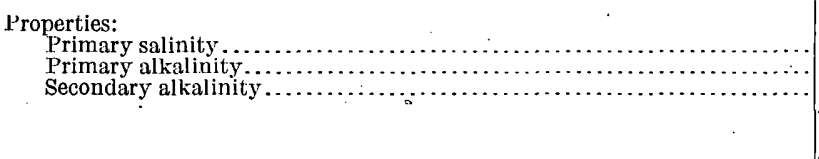 } & $\begin{array}{r}13.7 \\
6.6 \\
79.7\end{array}$ & $\begin{array}{r}18.2 \\
6.9 \\
74.9\end{array}$ \\
\hline & 100.0 & 100.0 \\
\hline \multirow[t]{2}{*}{ 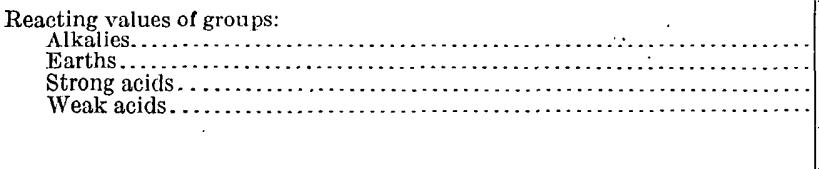 } & $\begin{array}{r}10.16 \\
39.84 \\
6.85 \\
43.15\end{array}$ & $\begin{array}{r}12.54 \\
37.46 \\
9.08 \\
40.92\end{array}$ \\
\hline & 100.0 & 100.0 \\
\hline \multirow[t]{2}{*}{ 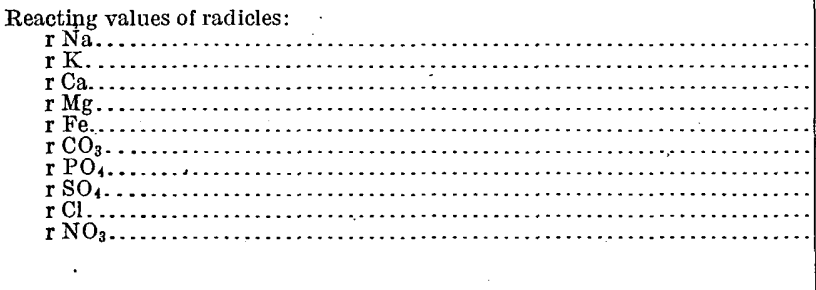 } & $\begin{array}{r}8.69 \\
1.47 \\
26.54 \\
13.02 \\
.28 \\
42.41 \\
.74 \\
.78 \\
1.97 \\
4.10\end{array}$ & \begin{tabular}{r}
8.57 \\
3.97 \\
25.32 \\
12.14 \\
\hdashline$\ldots . .9$ \\
40.92 \\
$\cdots . .84$ \\
3.84 \\
.77 \\
4.47
\end{tabular} \\
\hline & 100.0 & 100.0 \\
\hline
\end{tabular}

1 Jour. Chem. Soc., 1873, p. 229.

2 Kyle, J. J. J., Chem. News, vol. 38, 1878, p. 28. 
Character of Mahanuddy and Uruguay rivers-Continued.

\begin{tabular}{|c|c|c|}
\hline & Mg. per liter. & Mg, per liter. \\
\hline $\begin{array}{l}\text { Total dissolved ................ } \\
\text { Colloids: }\end{array}$ & 86.0 & 39.8 \\
\hline 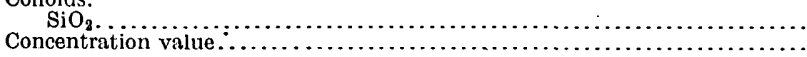 & $\begin{array}{l}27.8 \\
2.438\end{array}$ & $\begin{array}{l}18.5 \\
0.782\end{array}$ \\
\hline
\end{tabular}

Mr. Kyle's official duties in. connection with choosing a suitable water supply for Buenos Aires afforded him unusual opportunity to learn the character and quality of many rivers in the surrounding territory. A subsequent report by Kyle shows that primary alkalinity is not confined to Uruguay River but is characteristic of many rivers in the same drainage area.

Kyle's description of the appearance of Uruguay River, of its purity, and of the siliceous character of its water deserves to be quoted:

The water of the river Uruguay is in some respects very remarkable. It is probably one of the purest river waters in the world, containing rather less than 4 parts of solid matter per 100,000. It is almost free from chlorides; the determination of chlorine, made with every possible care, gave rather less than one-fourth of a milligram per liter, and this, be it remembered, at a distance of say 500 miles from its source.

Still more noteworthy, in my opinion, is the fact that about 46 per cent of the total solid matter consists of soluble silica, not suspended as in the other two rivers. A gmall proportion exists probably as alkaline silicate, but the greater part is undoubtedly present as hydrated silicic acid. In this circumstance may be found an explanation of the petrifying properties attributed to the water of the Uruguay. On one occasion a cart wheel was fished up from its bed completely converted into stone. A considerable export trade in agates is carried.on by the inhabitants on the Uruguayan shores of this great river, and the stones from the Uruguay are; I believe, those most esteemed by European lapidaries. The free silicic acid dissolved by this river among the mountains of Santa Catharina, in Brazil, is probably the raw material out of which are elaborated the agate mortars so invaluable to every analytical chemist.

PERSISTENCE OF SILICA IN RIVER WATERS.

The percentage values of the primary and secondary alkalinity of the Ottawa, Mahanuddy, and Uruguay River waters as obtained from the character formulas are repeated here for comparison.

Alkalinity of Ottawa, Mahanuddy, and Uruguay rivers.

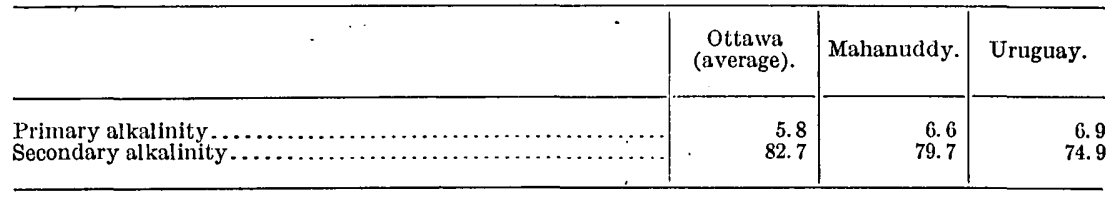

The percentage of silica in the dissolved inorganic material is, for Ottawa River, 29; for Mahanuddy River, 32; and for Uruguay River, 46 .

Kyle's results show that the high proportion of silica in the inorganic material of Uruguay River can not be correlated with dis- 
solved organic matter but may, on the contrary, be due, in part at least, to the absence of organic matter. The Uruguay, in latitude $27^{\circ}$ to $36^{\circ}$ south, occupies in the Southern Hemisphere a position closely corresponding to that of the Piedmont Plateau and Coastal Plain area, between latitudes $30^{\circ}$ and $38^{\circ}$ north. Mahanuddy River is tropical; the Ottawa flows in the far north. The waters of all these rivers are primary-alkaline, and, irrespective of climate, all of them show a tendency favorable to the retention of silica. Their story corroborates the story told by the rivers of our own land. The high proportion of silica, moreover, in the mineral content of the waters of these three great rivers, draining granitic areas in widely separated parts of the earth, indicates that as a prominent constituent of the dissolved material, silica in river waters is not necessarily confined to the waters near the sources of the streams. On the contrary, the evidence tends to show that silica may constitute a large part of the material in the water of rivers at remote distances from their sources, if the conditions are such as to maintain the primary alkalinity of their waters.

The actual state of silica in highly dilute solution may not be perfectly understood and these observations do not bear directly on its physical condition, but it is hoped that they will show the propriety of interpreting mineral analyses of water according to modern chemical principles.

THE WATER OF MISSISSIPPI RIVER.

The interpretation of a series of analyses of the water of Mississippi River made by chemists of the United States Geological Survey reveals the changes in the character of the water of a great river at different points. . As shown in Table 4, the water of the Mississippi at Minneapolis is very simple in character, being distinguished only by secondary alkalinity, primary salinity, and very low secondary salinity or permanent hardness. In these qualities the water of the Mississippi resembles the water of the Shenandoah at its mouth. At Moline, Ill., permanent hardness appears definitely among the properties of the Mississippi water, although it occupies a very subordinate position. It should be observed that the proportion of primary salinity in the water of the upper Mississippi remains practically constant for the entire distance between Minneapolis, Minn., and Quincy, Ill., thus constituting an important feature of the water of this part of the river. At Chester, Ill., the character of the water appears to be greatly changed, for the analyses indicate that the proportion of primary salinity is much increased and the proportion of permanent hardness-that is, secondary salinity-is more than doubled. 
TABLE 4.-Character of water of Mississippi and Missouri rivers.

\begin{tabular}{|c|c|c|c|c|c|c|c|c|c|c|c|c|c|c|c|}
\hline & \multicolumn{6}{|c|}{ Mississippi above mouth of Missouri. } & \multicolumn{6}{|c|}{ Mississippi below mouth of Missouri. } & \multirow{2}{*}{\multicolumn{2}{|c|}{$\begin{array}{l}\text { Missouri at mouth. } \\
\text { At Ruegg, Mo. a b }\end{array}$}} & \\
\hline & \multicolumn{2}{|c|}{ At Minneapolis, Minn. a b } & \multicolumn{2}{|c|}{ At Moline, Mll. a c } & \multicolumn{2}{|c|}{ At Quincy, Ill. a c } & \multicolumn{2}{|c|}{ At Chester, Il. $a c$} & \multicolumn{2}{|c|}{ At Memphis, Tenn. a d } & \multicolumn{2}{|c|}{ At New Orleans, La.be } & & & \\
\hline $\begin{array}{l}\text { Properties. } \\
\text { Primary salinity........... } \\
\text { Secondary salinity ....... } \\
\text { Secondary alkalinity...... }\end{array}$ & \multicolumn{2}{|c|}{$\begin{array}{c}\text { Per cent. } \\
12.1 \\
.6 \\
87.3\end{array}$} & \multicolumn{2}{|c|}{$\begin{array}{c}\text { Per cent. } \\
13.8 \\
6.6 \\
79.6\end{array}$} & \multicolumn{2}{|c|}{$\begin{array}{c}\text { Per cent. } \\
13.2 \\
6.0 \\
80.8\end{array}$} & \multicolumn{2}{|c|}{$\begin{array}{l}\text { Per cent. } \\
20.6 \\
13.7 \\
65.7\end{array}$} & \multicolumn{2}{|c|}{$\begin{array}{c}\text { Per cent. } \\
21.9 \\
8.4 \\
69.7\end{array}$} & \multicolumn{2}{|c|}{$\begin{array}{c}\text { Per cent. } \\
19.9 \\
11.3 \\
68.8\end{array}$} & \multicolumn{2}{|c|}{$\begin{array}{l}\text { Per cent. } \\
27.8 \\
18.8 \\
53.4\end{array}$} & \multirow[t]{2}{*}{\begin{tabular}{|l}
\multicolumn{1}{c}{ Properties. } \\
Primary salinity. \\
Secondary salinity. \\
Secondary alkalinity.
\end{tabular}} \\
\hline & \multicolumn{2}{|c|}{100.0} & \multicolumn{2}{|c|}{100.0} & \multicolumn{2}{|c|}{100.0} & \multicolumn{2}{|c|}{100.0} & \multicolumn{2}{|c|}{100.0} & \multicolumn{2}{|c|}{100.0} & \multicolumn{2}{|c|}{100.0} & \\
\hline $\begin{array}{l}\text { oups: } \\
\text { Alkalies............. } \\
\text { Earths............. } \\
\text { Strong acids....... } \\
\text { Weak acids....... }\end{array}$ & $\begin{aligned} & \text { Per cent. } \\
& 6.04 \\
& 43.96 \\
& 6.36 \\
& 43.64\end{aligned}$ & $\begin{array}{r}\text { Mg. p.. liter. } \\
0.428 \\
3.117 \\
.451 \\
3.094\end{array}$ & $\begin{array}{r}\text { Per cent. } \\
6.86 \\
43.14 \\
10.18 \\
39.82\end{array}$ & $\begin{array}{r}\text { Mg. per liter. } \\
0.430 \\
2.705 \\
.638 \\
2.497\end{array}$ & $\begin{array}{r}\text { Per cent. } \\
6.60 \\
43.40 \\
9.62 \\
40.38\end{array}$ & $\begin{array}{r}\text { Mg.per liter. } \\
0.471 \\
3.096 \\
.686 \\
2.881\end{array}$ & $\begin{array}{c}\text { Per cent. } \\
10.29 \\
39.71 \\
17.14 \\
32.86\end{array}$ & \begin{tabular}{r|} 
Mg. per liter. \\
0.900 \\
3.472 \\
1.499 \\
2.873
\end{tabular} & $\begin{array}{c}\text { Per cent. } \\
10.96 \\
39.04 \\
15.16 \\
34.84\end{array}$ & \begin{tabular}{|l} 
Mg. per liter. \\
0.761 \\
2.713 \\
1.053 \\
2.421
\end{tabular} & $\begin{array}{r}\text { Per cent. } \\
9.96 \\
40.04 \\
15.61 \\
34.39\end{array}$ & \begin{tabular}{r|} 
Mg.per liter. \\
0.540 \\
2.170 \\
.846 \\
1.864
\end{tabular} & $\begin{aligned} & \text { Per cent. } \\
& 13.89 \\
& 36.11 \\
& 23.30 \\
& 26.70\end{aligned}$ & $\begin{array}{l}\text { Mg.per liter. } \\
1.517 \\
3.941 \\
2.544 \\
2.914\end{array}$ & \multirow{2}{*}{\begin{tabular}{l|l} 
& Reacting values. \\
& Groups: \\
7 & Alkalies. \\
& Earths. \\
4 & Strong acids. \\
4 & Weak acids. \\
6 & Concentration value.
\end{tabular}} \\
\hline Concentration value & 100.0 & 7.090 & 100.0 & 6.270 & 100.0 & 134 & 0.0 & 8. 744 & 100.0 & .948 & 0.0 & .420 & 00.0 & 10.916 & \\
\hline 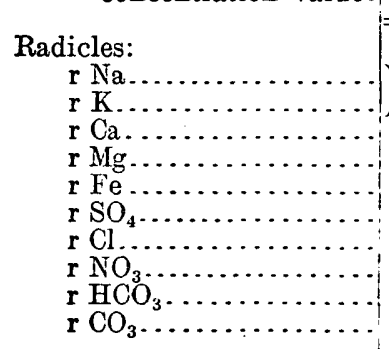 & \begin{tabular}{|c|} 
Formula. \\
6.04 \\
28.01 \\
15.94 \\
.02 \\
5.32 \\
.69 \\
.35 \\
43.64 \\
.0
\end{tabular} & \begin{tabular}{|r|} 
Mg.per liter. \\
0.428 \\
1.985 \\
1.130 \\
.002 \\
.377 \\
.049 \\
.025 \\
3.094 \\
.0
\end{tabular} & $\begin{array}{r}\text { Formula. } \\
6.86 \\
26.14 \\
16.81 \\
.19 \\
8.01 \\
1.72 \\
.45 \\
39.82 \\
.0\end{array}$ & \begin{tabular}{|r|} 
Mg. per liter. \\
0.430 \\
1.639 \\
1.054 \\
.012 \\
.502 \\
.108 \\
.028 \\
2.497 \\
.0
\end{tabular} & $\begin{array}{r}\text { Formula. } \\
6.60 \\
25.02 \\
18.17 \\
.21 \\
7.33 \\
1.80 \\
.49 \\
40.38 \\
.0\end{array}$ & \begin{tabular}{|r|} 
Mg. per liter. \\
0.471 \\
1.785 \\
1.296 \\
.015 \\
.523 \\
.128 \\
.035 \\
2.881 \\
.0
\end{tabular} & \begin{tabular}{r|} 
Formula. \\
10.29 \\
24.90 \\
14.66 \\
.15 \\
13.38 \\
3.24 \\
.52 \\
32.86 \\
.0
\end{tabular} & \begin{tabular}{|c|} 
Mg. per liter. \\
0.900 \\
2.177 \\
1.282 \\
.013 \\
1.170 \\
.283 \\
.046 \\
2.873 \\
.0
\end{tabular} & $\begin{array}{r}\text { Formula. } \\
9.86 \\
1.10 \\
26.35 \\
12.54 \\
10.54 \\
4.55 \\
4.07 \\
32.10 \\
2.74\end{array}$ & \begin{tabular}{|r|} 
Mg. per ititer. \\
0.685 \\
.076 \\
1.831 \\
.875 \\
.007 \\
.732 \\
.316 \\
.005 \\
2.231 \\
.190
\end{tabular} & \begin{tabular}{|r|} 
Formula. \\
9.96 \\
28.66 \\
11.38 \\
$\cdots . .45$ \\
9.40 \\
5.76 \\
34.39 \\
.0
\end{tabular} & \begin{tabular}{|c|} 
Mg. per liter. \\
0.540 \\
1.553 \\
.617 \\
$\cdots .612$ \\
.293 \\
.041 \\
1.864 \\
.0
\end{tabular} & $\left\{\begin{array}{r}\text { Formula } \\
12.37 \\
1.52 \\
23.84 \\
12.11 \\
1.16 \\
19.80 \\
3.08 \\
.42 \\
26.70 \\
.0\end{array}\right.$ & \begin{tabular}{|r|} 
Mg. per liter. \\
1.351 \\
.166 \\
2.600 \\
1.323 \\
.018 \\
2.162 \\
.336 \\
.046 \\
2.914 \\
.0
\end{tabular} & 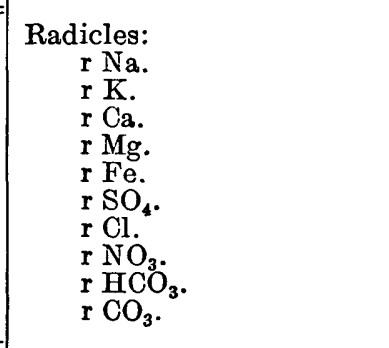 \\
\hline Concentration value. & 100.0 & 7.090 & 100.0 & 6.270 & 100.0 & 7.134 & 100.0 & 8. 744 & 100.0 & 6. 948 & 100.0 & 5.420 & 100.0 & 10.916 & Concentration value. \\
\hline 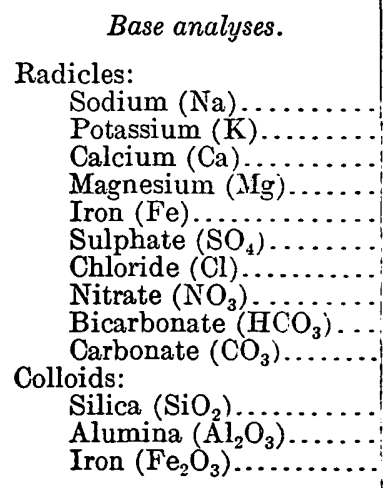 & $\begin{array}{r}\text { Parts per } \\
10 \\
40 \\
14 \\
18 \\
1 \\
1 \\
188 \\
15\end{array}$ & $\begin{array}{l}r \text { million. } \\
.0 \\
.0 \\
1.0 \\
.07 \\
.0 \\
.6 \\
.4 \\
.0 \\
.0 \\
5.0\end{array}$ & $\begin{array}{r}\text { Parts pe } \\
10 \\
33 \\
13 \\
24 \\
3 \\
1 \\
152 \\
16\end{array}$ & $\begin{array}{l}\text { million. } \\
.0 \\
.0 \\
.0 \\
.39 \\
.0 \\
.7 \\
.8 \\
.0 \\
.0 \\
.0\end{array}$ & $\begin{array}{r}16 \\
25 \\
5 \\
2 \\
175\end{array}$ & $\begin{array}{l}0 \\
46 \\
0 \\
2 \\
0 \\
0\end{array}$ & $\begin{array}{r}\text { Parts per } \\
21 \\
44 \\
16 \\
56 \\
9 \\
2 \\
174\end{array}$ & million. & \multicolumn{2}{|c|}{$\begin{array}{c}\text { Parts per million. } \\
16.0 \\
3.0 \\
37.0 \\
11.0 \\
.3 \\
35.0 \\
11.0 \\
.33 \\
135.0 \\
5.7\end{array}$} & $\begin{array}{r}\text { Parts per } \\
13 \\
32 \\
8 \\
-3 \\
24 \\
9 \\
2 \\
111 \\
\\
11\end{array}$ & $\begin{array}{l}.0 \\
.4 \\
.0 \\
.7 \\
.5 \\
0 \\
.0 \\
.0 \\
.4\end{array}$ & \multicolumn{2}{|c|}{$\begin{array}{c}\text { Parts per million. } \\
31.0 \\
6.5 \\
52.0 \\
16.0 \\
.51 \\
104.0 \\
12.0 \\
2.9 \\
178.0 \\
.0\end{array}$} & $\begin{array}{l}\text { Base analyses. } \\
\text { Radicles: } \\
\text { Sodium (Na). } \\
\text { Potassium (K). } \\
\text { Calcium }(\mathrm{K}) . \\
\text { Magnesium }(\mathrm{Mg}) . \\
\text { Iron }(\mathrm{Fe}) . \\
\text { Sulphate }\left(\mathrm{SO}_{4}\right) . \\
\text { Chloride }(\mathrm{Cl}) \cdot \\
\text { Nitrate }\left(\mathrm{NO}_{3}\right) \\
\text { Bicarbonate }\left(\mathrm{H}^{2} \mathrm{CO}_{3}\right) . \\
\text { Carbonate }\left(\mathrm{CO}_{3}\right) . \\
\text { Colloids: } \\
\text { Silica }\left(\mathrm{SiO}_{2}\right) . \\
\text { Alumina }\left(\mathrm{Al}_{2} \mathrm{O}_{3}\right) . \\
\text { Iron }\left(\mathrm{Fe}_{2} \mathrm{O}_{3}\right) .\end{array}$ \\
\hline $\begin{array}{l}\text { Total dissolved solids. } \\
\text { umber of composites....... } \\
\text { ates..................... }\end{array}$ & $\begin{array}{r}200 \\
35 \\
\text { Sept. 10, } 1 \\
11,1907\end{array}$ & 0 & $\begin{array}{r}179 \\
\text { Feb. } 1,18 \\
\text { 31, } 1907\end{array}$ & 1906-July & $\begin{array}{r}203 \\
\text { Apr. } 1, \\
31,1907\end{array}$ & 6-July & $\begin{array}{r}269 \\
32 \\
\text { Aug. } 1, \\
\text { 31, } 1907\end{array}$ & 6-July & $\begin{array}{r}209 \\
\\
11 \\
\text { Sept. } 9 \\
1,1908 .\end{array}$ & 1907-Jan. & $\begin{array}{r}166 \\
52 \\
\text { Apr. } 29 \\
\text { 23. } 1906\end{array}$ & 1905-Apr. & $\begin{array}{r}346 \\
36 \\
\text { Sept. } 27 \\
6,1907 .\end{array}$ & 0 & $\begin{array}{l}\quad \text { Total dissolved } \\
\text { solids. } \\
\text { Number of composites. } \\
\text { Dates. }\end{array}$ \\
\hline
\end{tabular}

a A verages of analyses of composite samples-each composite consisting of 10 daily collections.
o Reported in W Water-Supply Paper U. S. Geol. Survey No. 236, 1909.

c Reported with descriptions and details by W. W. Collins; Quality of surface waters of Illinois: Water-
Supply Paper U. S. Geol. Survey No. 239, 1910 .

d Analyses by R. B. Dole, W. D. Collins, and Chase Palmer.
e A verage of analyses of composite samples, each composite consisting of 7 daily collections.

95451-Bull. 479-11. (To face page 28.) 
The proportional variation that has taken place in the properties of the river water between Quincy and Chester is the same in kind as the change commonly. observed in the properties of a chemical reagent if the proportions of the salts dissolved in it are changed. The principal cause of the change in the proportions of properties observed in the water of the Mississippi at Chester is the highly saline water poured by the Missouri into the Mississippi at a point between Quincy and Chester. From Chester to New Orleans the river water appears to undergo no permanent change in general character. In the water at Memphis the analyses indicate temporary reduction in secondary salinity, probably due in large measure to water brought in by Ohio River. Additional contributions of saline waters from the West, received through Arkansas and Red rivers, suffice to maintain in the water of the lower Mississippi that high proportion of salinity first derived midway in its course from Missouri River.

The changes in the character of the waters of the upper and lower. Mississippi show the manner in which salinity may be developed in the water of a river whose drainage basin contains large areas of sedimentary rocks.

\section{THE WATER OF THE GREAT LAKES AND ST, LAWRENCE RIVER.}

The changes in the character of the water of the St. Lawrence River system occur in somewhat different order from that observed. in the course of the Mississippi, and may be traced through the Great Lakes by interpretations of recent analyses by Dole and Roberts. ${ }^{1}$ As Lake Superior occupies a higher and more westerly position than the other lakes, it will be considered first.

The interpretation presented in Table 5 indicates that the water of Lake Superior-the largest body of fresh water on the globe-is distinguished by primary alkalinity. The water of Lake Michigan is very different from that of Lake Superior, as the samples show properties characteristic of a water coming from a region of sedimentary rocks, and a distinct resemblance is shown between the water of Lake Michigan and that in the lower part of Lake Huron.

At Buffalo, N. Y., the total primary and secondary salinity of the water of Lake Erie shows an increase of 9 per cent over the proportion of the same properties in the water of Lake Huron. That this conspicuous change in the character of the water of the Great Lakes is caused by local conditions may be inferred from the fact that no further change of properties in the same direction is observable in the water at Ogdensburg, N. Y., even after its long journey through Lake Ontario. The character formula of Lake Erie water discloses at once the fact that the remarkable increment in the proportion of salinity in the lake water is caused by chlorides and sulphates and suggests 
the advent of brines, known to abound among the rocks in the drainage area of Lake Erie. One of the most important streams draining this area is the Maumee, whose water, where it enters the upper end of Lake Erie, closely approaches a brine in character. Since the character formula is distinctively a rational expression, the reacting ratios of the radicles in the formula can be obtained directly from their percentage values. In the formula it will thus be seen that the value of the chlorides exceeds the total value of the alkalies. This relation is exceptional in river waters and may be charged directly to the waste brines that flow into Maumee River from the numerous oil wells of the district. The excess of chlorides of the alkaline earths over alkaline chlorides is not peculiar to the brines of Ohio. In the salt water already mentioned as occurring at Highland, Ill., a similar condition may be seen. In localities where salt is produced as a commercial article from Ohio brines, the excess of alkaline earth chlorides is sufficient to warrant the separate manufacture of calcium chloride, and this compound is reported to be a very profitable by-product of the salt industry.

From the values in the character formula the relative reacting values of the different radicles may be traced. The ratios of the reacting values of sodium and chlorine in the Great Lakes, chlorine being 1 , are shown below:

Sodium in Great Lakes.

Lake Superior. ............................... 4

Lake Michigan .................................... 7

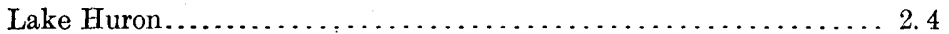

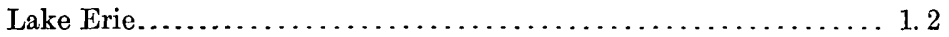

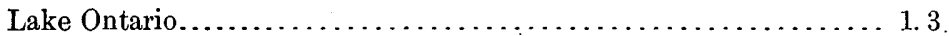

The ratio for the water of Lake Ontario is taken from the analysis of the St. Lawrence River water at Ogdensburg, N. Y.

In the Mississippi River water a similar progressive advance of chlorine on sodium is also observed. The ratios are shown below, chlorine being unity.

Sodium in Mississippi River.

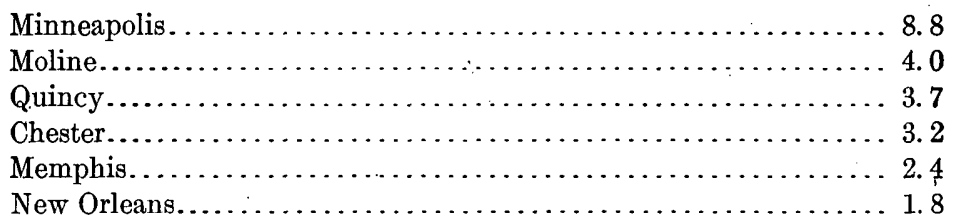

The progressive advance of chlorine on sodium in the water of the Mississippi and of the Lakes shows lines along which flowing water develops salinity as it traverses sedimentary rocks.

As the water from Lake Ontario enters the channel of St. Lawrence River it becomes subject to conditions prevailing in a region of ancient crystalline rocks. The change in character resulting from change 
TABLE 5.-Character of water of St. Lawrence basin.

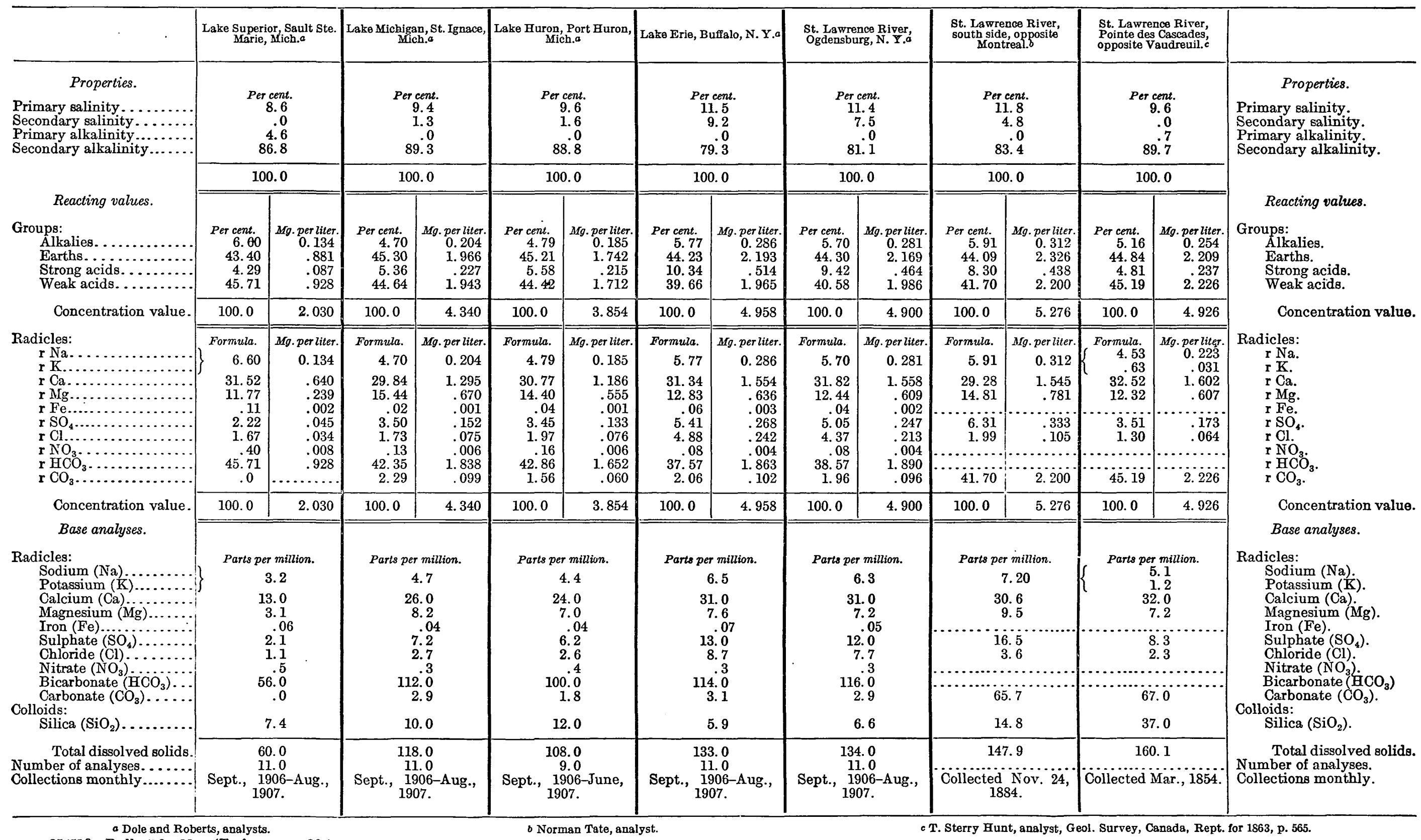

a Dole and Roberts, analysts.
$95451^{\circ}-$ Bull. $479-11 . \quad$ (To face page 30 .)

b Norman Tate, analyst.

c T. Sterry Hunt, analyst, Geol. Survey, Canada, Rept. for 1863, p. 565. 
in environment appears in the interpretation of analyses of the water at. Ogdensburg, N. Y. (Table 5). Between Buffalo, on Lake Erie, and Ogdensburg no appreciable change appears to have occurred in the amount of soluble material contained in the water, but a decided reduction is evident in the concentration value of the solution. The change in this value, coincident with a change in the proportions of the properties of the solution, while the weight of the dissolved salts remains practically constant, should not be overlooked. That this incipient reversion from salinity to alkalinity is due to environment is manifest. It is only necessary to recall the fact that directly below the point at which samples of the St. Lawrence water were collected Oswegatchie River is adding primary-alkaline water, brought from the Adirondacks, to reduce the secondary salinity of the St. Lawrence waters, which reached. its maximum at Buffalo.

For judging the chemical character of the St. Lawrence River water below Ogdensburg the available data are very limited. An analysis made in $1884^{1}$ of the river water collected on the south side of the river opposite Montreal shows a still further reduction in the proportion of secondary salinity, and is in perfect accord with the inference that might follow the consideration of what is known to be going on at the upper end of the St. Lawrence River channel.

Even more striking is a very early analysis of the river water made by T. Sterry Hunt. The water was collected in the main St. Lawrence just above the most westerly outlet of the Ottawa, in the same month and year in which the sample was taken for the analysis of the Ottawa River water that has already been considered. The complete reversion of secondary salinity to alkalinity indicated at this point should not be taken too seriously, for a temporary eddying of the waters may have caused admixture of the river water with a primary water. At all events the tendency of the St. Lawrence water to revert to a primary-alkaline water is abundantly shown. Below the city of Montreal the Ottawa enters the St. Lawrence by two additional channels, and about 45 miles below Montreal the Richelieu is adding its alkaline waters brought from Lake Champlain. With the data at hand it is impossible to state with certainty how far the work of restoration brings back the character of the water of the St. Lawrence to the character of the water of Lake Superior. In the regional study of waters there is much to be done, and great profit is to be expected from work in this field.

\section{CONCLUSION.}

In this preliminary consideration of water analyses sufficient ground has been covered to justify the conclusion that natural water may be definitely characterized if the salts dissolved in it are recognized not as a load but as a chemical system of balanced values.

\footnotetext{
1 Analysis by Norman Tate; published by T. Mellard Reạdę in Evolụtion of ẹarth structure, 1903, p. 265.
} 